\title{
Izotopii generatoare de clișee jurnalistice în contextul pandemiei de Covid-19: „patologii la modă” sau „cuvinte-oglindă” ale realității psihosociale?
}

\author{
Armanda Ramona Stroia ${ }^{\star}$ \\ Facultatea de Litere, Universitatea Tehnică din Cluj-Napoca, Centrul Universitar Nord, Str. Victoriei 76, 430122 Baia Mare, România
}

\section{Despre articol}

Istoric:

Primit 16 octombrie 2020

Acceptat 19 noiembrie 2020

Publicat 27 decembrie 2020

Cuvinte-cheie:

clișeu lingvistic

discurs media

izotopie

infodemie

pandemie

Covid-19

sociologie

\begin{abstract}
Rezumat
Demersul investigativ de față propune o „cartografiere” a izotopiilor dominante generatoare de clișee lingvistice, în contexul mediatizării intense a pandemiei actuale de Covid-19. Analiza automatismelor lingvistice extrase din discursul jurnalistic online ne-a oferit indicii relevante, nu doar pentru a identifica particularități noi ale „comportamentului” lingvistic al clișeelor, ci şi pentru înțelegerea mizelor, implicațiilor și posibilelor efecte ale utilizării anumitor structuri prefabricate. În principiu, examinarea acestor scheme de clișeizare a relevat modul în care instanțele mediatice preiau, sub presiunea modelului internaţional, izotopiile lexico-semantice care exploatează structuri prefabricate din domenii distincte: războiul, cu predilecție zona elementelor pirotehnice (,au explodat cazurile”, „explozie de noi cazuri”, „explozie uriașă de cazuri de Covid”), aria semantică a dezastrelor naturale subsumată lichidității („un nou val de COVID”, „val de controale anti-Covid”, „val de decese”, „un val de comentarii pline de ură, „val de infectări/ de confirmări/ de îmbolnăviri”, „potop de acuzații/ de amenzi”, „tsunami de bolnavi de Covid-19 / de concedieri”). De asemenea, am identificat automatisme jurnalistice circumscrise izotopiei economiei („bilanţul epidemiologic”), clasamentului și competiției sportive (clișee ale statisticilor: „topul infectărilor”, „topul Covid”, „topul îmbolnăvirilor cu Covid”, „topul european al evoluției Covid”, „cursa vaccinurilor” etc.), dezastrului (clișee ale excesului melodramatic, simptomatice jurnalismului de tip tabloid: „dezastru”, „haos”, „coşmar”, „drama Covid-19”). Efortul analitic a fost concentrat, pentru articolul de față, asupra primelor două izotopii dominante.

Pentru a atinge aceste obiective, am propus un model de cercetare bidimensional, axat pe corelarea datelor obținute din unghiuri diferite, atît în funcție de microparametri lingvistici (valențe semantice, stilistice, tipare lexicale și morfosintactice), cît și de variabile macrocontextuale (aspecte pragmatice, psiholingvistice, perspective derivate din sociologia comunicării media, analiza critică a discursului etc.).

Rezultatele investigației au evidențiat că aceste șabloane lingvistice, analizate în „acolada” conceptuală a izotopiilor, pot funcționa ca strategii retorice și lexico-semantice prin care jurnalistul activează energiile afective ale receptorilor. Se creează astfel stări artificiale de neliniște, panică, anxietate. În timp, această operație, conduce, prin impactul repetiției obsesive, la consumul pasiv de reprezentări mediatice și stereotipuri culturale, de idei preconcepute.
\end{abstract}

${ }^{\dagger}$ Acest articol examinează cîteva clișee lingvistice din media socială: cafeneauadetraduceri.ro.

*Adresă de corespondență: armanda_ramona@yahoo.com. 


\section{Considerații preliminare}

Pe fondul infodemiei $i^{1}$ și al unui ansamblu de factori (biologici, sociali, politici), se exercită influențe semnificative care contribuie la (re)modelarea percepțiilor, atitudinilor și interpretărilor atribuite realității actuale, marcate de răspîndirea noului coronavirus (Covid-19). În acest context, al unei societăți puternic interconectate digital, rețelele mediatice și platformele de socializare alimentează un discurs şi o cultură a anxietății, a incertitudinii. Această practică a mass-mediei are implicaţii multiple la nivelul tiparelor socioculturale, comportamentale, mentale, discursive, politice și economice. Astfel, efectele sunt vizibile în polarizarea dezbaterii publice, subminarea răspunsurilor și a acțiunilor din domeniul sănătății, amplificarea riscului de conflict, a unui discurs al urii și prejudecăților, amenințarea perspectivelor pe termen lung ale drepturilor omului, intensificarea fenomenului de stigmatizare socială etc. La nivel lingvistic, metaforele și expresiile prefabricate, clişeizate pot deveni vectori de manipulare în contul promovării unor interese și agende alternative ale unor grupuri sau instituții.

\section{Clișeul lingvistic și funcțiile sale: un „aisberg” conceptual}

În sens restrîns, dintr-un punct de vedere reductiv, clișeele sînt percepute strict prin dimensiunea peiorativă, ca expresii uzate, desuete, denunțate în uzul cotidian. Cu toate acestea, analiza funcțiilor ${ }^{2}$ într-un context mai larg, interdisciplinar, relevă valențe adiacente: funcția ideologică din perspectiva filosofiei politice a limbajului (Porter, 2010; Berger, 2011; Mackay, 2014; Norberg, 2014), respectiv un set de funcții din prisma științelor limbajului, teoriilor lecturii și receptării ${ }^{3}$.

De asemenea, prin „filtrul” psihologiei sociale (Zijderveld, 1979) devine transparent rolul automatismelor în crearea punților de conexiune, de identificare cu alteritatea pe baza însuşirii competenței socioculturale a comunității (Stark, 1999). În esență, prin această grilă de interpretare, structurile prefabricate funcționează ca sursă a stabilității și familiarului într-o lume suprasaturată de informație și stimuli, caracterizată de instabilitate emoțională și incertitudine existențială, devenind un factor de coeziune a societății moderne ${ }^{4}$.

Percepțiile divergente asupra funcțiilor acestor șabloane lingvistice polarizează dezbaterea între atitudini radicale: de la sancționarea acestui tip de „reproducere devalorizantă”, a acestei „mode” lingvistice nejustificate (Guțu Romalo, 2008; Paraschivescu, 2009; Gruiță, 2011), la o abordare pozitivă (Amossy \& Rosen, 1982; Bagnall, 1985; Zafiu, 2001; Dumistrăcel, 2006; Amossy \& Herschberg-Pierrot, 2011; Hargraves, 2014; Duda, 2016). Prima direcție, înrădăcinată în aversiunea romantică asupra locului comun, în dezavuarea modernă a banalității, atinge, uneori, un paroxism, un extremism în evitarea obsesivă a ideilor primite, perimate. Devalorizarea automatismului verbal este evidentă în etichete peiorative precum „stîngăcie lingvistică” asociată subculturii, în perceperea acestuia ca emblemă a banalității triviale, a literaturii

\footnotetext{
${ }^{1}$ Este un termen recent introdus în discursul public, fenomenul infodemiei fiind definit de Organizația Mondială a Sănătății ca „an overabundance of information—some accurate and some not-occurring during an epidemic. It makes it hard for people to find trustworthy sources and reliable guidance when they need it" [online].

${ }^{2}$ Duda (2016) evidențiază un set de funcții al automatismelor lingvistice derivate pe baza unei analogii cu modelul funcțional al lui Jakobson: clișee cu funcție persuasivă, critică, metadiscursivă, discursivă, fatică.

${ }^{3}$ Structurile clișeizate au fost resemantizate pozitiv, cu funcții argumentative, constructive și fatice: „Cînd scriitorul folosește un clișeu, participă într-un fel de substratum cultural recunoscut” (Stark, 1999, p. 454).

${ }^{4}$ Sociologul cultural Zijderveld (1979) percepe modernitatea ca rezultat al substituirii semnificației cu funcționalul, ceea ce a dus la apariția societății contemporane clişeizate, caracterizate prin pierderea unicității. În acest context, în percepția teoreticianului, clișeele devin embleme/semnale verbale ale modernității, urbanizării, birocrației. Sociologul cultural examinează funcția socială și politică a clișeului în societatea modernă și evidențiază faptul că automatismele lingvistice sînt ingrediente indispensabile ale comunicării cotidiene. $\mathrm{Cu}$ alte cuvinte, adeziunea la convențional, la cognoscibil, familiar, prin intermediul automatismelor cotidiene, verbale sau comportamentale, oferă funcția—validată social—a protecției împotriva unei realități incerte, golite de sens. Așadar, în ciuda faptului că eșuează în a transmite semnificație, clișeele funcționează din punct de vedere social și joacă, prin urmare, un rol vital în coagularea societății fracturate, atomizate (vezi Zijderveld, 1979, p. 53).
} 
şi culturii de consum, ca simbol al mediocrităţii: „Linguistic gaucherie, used mainly by the subarticulate and [...] participants in middle and «low-brow culture»" (Suhor, 1975, p. 159).

Pe de altă parte, a doua direcție își legitimează demersul de reabilitare a clișeului prin redescoperirea și valorificarea filonului retoricii antice pentru a susține statutul polivalent, dar și funcțiile constructive, estetice ale secvențelor prefabricate. Acest aspect este vizibil fie din prisma utilizării conștiente, deseori în cheie parodică a „limbii cu fixativ”, a „limbajului la indigo” (Paraschivescu, 2009, p. 55), fie ca marcă a unei tendințe de reevaluare favorabilă, înregistrată în științele sociale (psihologie socială, sociologia comunicării de masă), pragmatica contemporană, argumentarea și retorica politică, didactica limbilor străine, teoriile lecturii și receptării (intertextualitate, clișee tematice pentru coerența textuală).

Pentru a sintetiza, interpretarea prin optica normativă instituie, de regulă, un semn de echivalență între clișeu și abatere, ca simptom negativ al unei „patologii verbale” (Duda, 2016, p. 17). La polul opus, privit din perspectiva lingvistică a limbajului ca tranzacție (vezi teoriile contractualiste ale Școlii franceze) între instanța de enunțare și receptor, clișeul „nu mai pare atît de blamabil, ci devine un simbol util al identificării” (Bagnall, 1985, p. 20).

În ciuda receptării marcate de capitalul semantic peiorativ dat de „stigmatul banalităţii” (Amossy \& Rosen, 1982, p. 128) și de percepția de „fosilă lingvistică” (Nina, 1998, p. IV) a limbii de lemn, o analiză care se întinde dincolo de observațiile de suprafață ale perspectivei normative poate dezvălui partea invizibilă a acestui „aisberg”: un profil conceptual complex, un „paradox comunicaţional” (Quéré, 1998, p. 101), cu nuanțe caleidoscopice, prin diferitele sale niveluri de semnificație, dar și prin multitudinea de funcții pe care le poate (re)activa în discurs (vezi Fig. 1).

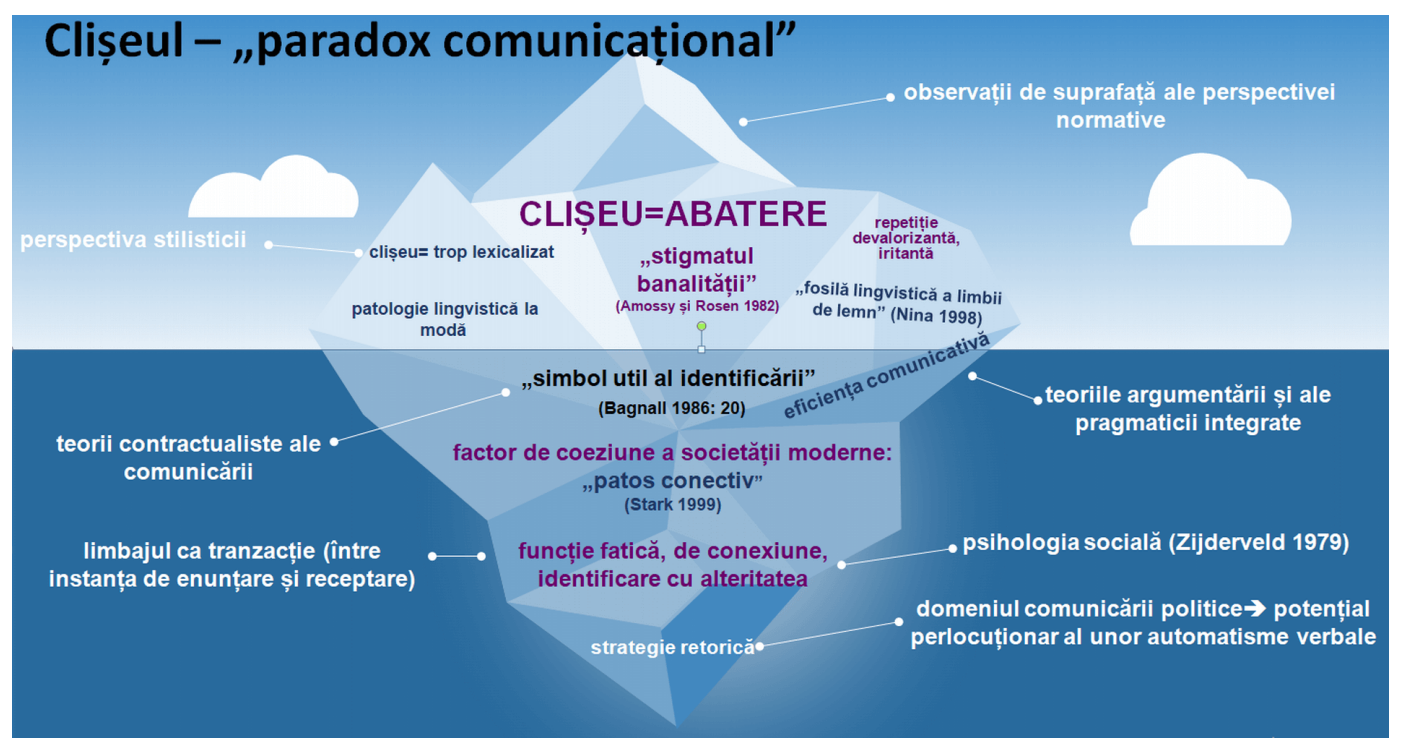

Figura 1: Clișeul lingvistic - un „aisberg” conceptual

\subsection{Profilul unui concept interdisciplinar. Repere, precizări terminologice și disocieri conceptuale}

Pentru a avea o imagine de ansamblu asupra fenomenului clișeizării, am corelat direcțiile teoretice dominante din domenii diferite, avînd în vedere contribuții relevante, derivate fie din disciplinele sociale (Zijderveld, 1979; Berger, 2011), științele limbajului (Bagnall, 1985; Olson, 1985; Stark, 1999; Amossy \& Herschberg-Pierrot, 2011), teoriile lecturii și receptării (Eco, 1979; Riffaterre, 1979), didactica lecturii (Dufays, 1994) sau chiar aspecte decelate din teoria politică și filosofia limbajului (Arendt, 2006; Norberg, 2014).

Un element de consens în metadiscursul asupra clișeului îl constituie reliefarea unui aspect semantic esențial: sublinierea ideii că sensul referențial este dimensiunea, trăsătura cea mai ștearsă a clișeului. $\mathrm{Cu}$ alte cuvinte, analiștii fenomenului acuză în mod constant „absența conținutului referențial, care este mai 
degrabă rezultatul unei ocurențe mașinale, decît fructul unei reflecții motivate tr.n.” (Nina, 1998, p. 66). Pentru a înțelege mai bine, autoarea citată ilustrează această particularitate semantică cu exemple de vid referențial în structurile clișeizate din mesajele funerare (în acest sens, vezi și Felecan, O., 2009), unde se exploatează „un semnificant al cărui referent ar putea fi complet diferit, vid sau neutru” (Nina, 1998, p. 66). În ciuda entropiei referențiale imputată automatismelor lingvistice, utilizarea acestor structuri prefabricate în discursul mediatic reflectă, la o examinare mai atentă, sub aspect conceptual și funcțional, pe lîngă "tendința spre brevilocvență, ca modalitate de manifestare a comodității și a minimului efort” (Felecan, D., 2009, p. 267), și mutaţiile/convulsiile sociopolitice dominante. În mod concret, în cazul unor momente de tensiune-fie de natură economică, ideologic-religioasă sau politică la nivel (inter)național—clișeele crizei, catastrofalului, ale terorismului sau ale maladivului domină discursul mediatic. Prin urmare, acestea pot fi percepute drept „cuvinte-martor” (fr. mot-témoin) în accepția lui Guilbert (1975, p. 87-88) sau am putea spune că joacă rolul de cuvinte-oglindă ale realității evenimențiale, nu în sensul în care ar încapsula, in nuce, o diagnoză sociopolitică, ci, mai degrabă, pentru că reflectă oforma mentis tipică societății marcate de efervescența globalizării și de consumul exponențial de informație.

O analiză pertinentă a clișeului lingvistic impune o raportare a statutului acestuia la fenomenul-umbrelă al stereotipiei ${ }^{5}$. Prin urmare, precizăm că accepția cu care vom folosi termenul reflectă relația de subordonare, de integrare sub ,acolada” conceptuală a stereotipiei, mergînd, astfel, pe direcția consensuală relevată de bibliografia de specialitate din spațiul francofon și anglo-saxon (Perrin-Naffakh, 1985; Dufays, 1994; Amossy \& Herschberg-Pierrot, 2011) ${ }^{6}$.

\subsection{Elemente de genealogie, origine și istorie semantică: clişeul, avatar terminologic al doxei}

Pentru a clarifica originile și a înțelege percepțiile dominante, marcate de un halou al receptării negative, am considerat că se impune ca punct de plecare o incursiune în trecutul semantic și etimologic al clișeului. Astfel, reținem din istoria semantică a noțiunii de clișeu o fluctuație interesantă a mutațiilor de sens: de la conotația inițială, tehnică, în registru neutru (în strînsă conexiune cu jargonul tehnologic al printării, și, ulterior-1865 - cu domeniul artei fotografice), la impunerea valenței figurate, peiorative și, mai recent, la revalorizarea pozitivă.

Deși noțiunea în sine de clișeu este relativ nouă și o datorăm modernității, o retrospectivă atentă asupra preocupărilor legate de fenomenul structurilor repetitive relevă „germenii” ideii de secvențe prefabricate încă din Antichitate, unde „preocuparea, obsesia actuală pentru originalitate («moda originalităţiii)) ar fi fost incomprehensibilă" (Bagnall, 1985, p. 19), avînd în vedere faptul că retorica aristoteliană încuraja apelul la rezervorul de topoi. În acest context, clișeul și stereotipul (alături de alte noțiuni afiliate fenomenului stereotipiei), sînt, de fapt, „camuflaje” terminologice sau, altfel spus, avataruri ale vechiului concept doxa, cu rădăcini în retorica aristotelică (Amossy, 2002, p. 374).

Pentru a înțelege prevalența atitudinii preponderent negative, depreciative, în cazul acestor automatisme, trebuie avut în vedere un moment semnificativ de pe axa temporală a fenomenului. Stigmatizarea clișeului reprezintă, de fapt, o reacție motivată din punct de vedere estetic, puternic înrădăcinată în ideologia romantică, a promovării expresiei creative, originale, surprinzătoare.

\section{Particularități ale discursului mediatic actual}

\subsection{Coordonate teoretice: convergență a mediilor, jurnalism 3.0, produtilizatori}

O perspectivă de ansamblu asupra „fizionomiei” presei online în peisajul mediatic actual necesită o focalizare asupra sumei de factori interdependenți, specifici contextului socioistoric, care explică dimensiunea

\footnotetext{
${ }^{5}$ Clișeul este definit, cu predilecție, „ca stereotipie stilistică, sintagmă verbală fixă, cu expresivitate «tocită »” (ChelaruMurăruș, 2007, p. 13), cu alte cuvinte ca o categorie lexico-semantică marcată prin estomparea expresivităţii și desemantizare.

${ }^{6}$ Specialiștii în stilistica și semiologia structurilor prefabricate atribuie stereotipului o valoare generică, superioară, ce înglobează celelalte noțiuni afiliate.
} 
senzaționalistă și complexitatea acestui tip de discurs ${ }^{7}$. În acest sens, punctăm, printre altele, dezvoltarea spectaculoasă a tehnologiei, „metamorfozele” jurnalismului în era digitală, a rețelelor sociale și a culturii postadevăr, dar și rolul intertextualității și al hibridizării în estomparea granițelor dintre diferite tipuri de media. Nevoia de adaptare conduce la așa-numitul jurnalism hibrid, în care fenomene precum digitalizarea și convergența, "punctul de întîlnire între jurnalismul tradițional și noile platforme digitale” (Melinescu, 2013, p. 100), dimensiunea infotainmentului, presiunea „senzaționalismului dus la extrem” (Rad, 2013, p. 262), retrasează în permanență limitele tradiționale ale genurilor mediatice. Este suficient să ne gîndim la rolul intertextualității și al hibridizării în estomparea granițelor dintre diferite tipuri de media: ziarele online au legături web, forumuri de discuții, sondaje de opinie, precum și înregistrări audio şi video ale unor emisiuni televizate, în timp ce televiziunile anunță revista presei și invită cititorii să acceseze paginile web.

Schimbarea de paradigmă este vizibilă, așadar, în „permeabilitatea” la inovație, dar și în provocările turbo-jurnalismului actual, axat pe exploatarea funcției ambivalente a canalelor media. Cu alte cuvinte, se valorifică posibilitatea oricărui utilizator de a se transforma din consumator pasiv de informație în creator activ de conținut. Acestă nouă realitate este încapsulată la nivel lingvistic în hibridul conceptual sau „cuvîntul-valiză” produtilizatori ${ }^{8}$, situație în care receptorii (cititorii presei online, în cazul nostru) devin emițători (producători de conținut) și invers.

De asemenea, o altă particularitate dominantă a discursului mediatic o reprezintă expansiunea infotainmentului dinspre „yellow sau junk journalism”, jurnalismul de „pubelă” practicat de tabloide, axat pe „hrănirea” și stimularea „nevoii gurmande de senzaţional” (Drăgan, 2007, p. 654), înspre zona jurnalismului „serios”.

\subsection{Discursul media și paradigma constructivistă}

Dat fiind faptul că întregul nostru demers investigativ are ca suport de cercetare discursul mediatic, am considerat că se impune, într-o acoladă teoretică, o clarificare succintă a accepțiunii de discurs. Opțiunea noastră de a circumscrie demersul analitic perspectivei constructiviste are la bază alinierea viziunii cu cea promovată de această paradigmă teoretică prin filtrul căreia mass-media construiește o imago mundi schematizată, deturnată, uneori, de la real din cauza sistemului de mediere particular, pe baza unor operații și funcții jurnalistice specifice: agenda setting, frame analysis, selectarea și „ «împachetarea» informației întrun cadru, într-o schemă de interpretare a evenimentului” (Beciu, 2011, p. 129) etc. De altfel, sociologii și specialiștii în comunicarea mediatică consolidează paradigma constructivistă prin lansarea în circulație a unor concepte precum „fabricarea știrilor”, ,filtre media” (Steuter \& Wills, 2009, p. 162) pentru a sublinia că, în ciuda obiectivităţii pretinse, negocierea, tendința de rescriere și interpretare a realității se dovedesc a fi emblematice pentru modul de funcționare a dispozitivului mediatic.

\section{Demersul investigativ}

Cercetarea de față a fost alimentată de interesul pentru a înțelege, nuanța și dezvălui profilul complex și comportamentul lingvistic variat al clișeelor jurnalistice generate de discursul mediatic al pandemiei de Covid-19.

În acest sens, am valorificat suportul teoretic și metodologic preluat din științele limbajului, psihologia socială și studiile comunicării media. Pentru a atinge acest obiectiv, am propus un model de cercetare bidimensional, axat pe corelarea datelor obținute atît în funcție de microparametri lingvistici (valențe

\footnotetext{
${ }^{7}$ Această particularitate semiotică se cuvine corelată cu ,împrumutul” de strategii de dramatizare preluate de gazetarii români din lumea teatrului, începînd cu a doua jumătate a secolului al XIX-lea (a se vedea Zafiu, 2001; Stoichițoiu-Ichim, 2005; Dumistrăcel, 2017).

${ }^{8}$ Produtilizator (produser în limba engleză) este un termen care surprinde noua realitate mediatică de enriched media, fiind „lansat de cercetătorul australian Axel Bruns, cel care a consacrat noul tip de relație, în care se multiplică nu doar utilizatorii, prin capacitățile tehnice de recepție sporite, ci și numărul furnizorilor, practic echivalent cu cel al utilizatorilor” (Melinescu, 2013, p. 115).
} 
semantice, stilistice, tipare lexicale și morfosintactice), cît și de variabile macrocontextuale (aspecte pragmatice, psiholingvistice, perspective derivate din sociologia comunicării media, analiza critică a discursului etc.). Considerăm că această abordare din unghiuri multiple de investigație aduce un element de noutate în metodologia de analiză a clișeului. Concret, acest tip de analize pot contribui nu doar la decelarea unor particularităţi interesante care vizează „comportamentul” clișeului jurnalistic, ci și la oferirea unor explicaţii contextualizate pentru prezența anumitor tipuri de structuri prefabricate.

\subsection{Observații privind metodologia de constituire a corpusului. Dificultăți și limite}

Perspectiva metodologică adoptată derivă din nevoia de a constitui un corpus lingvistic cît mai relevant. În consecință, am optat pentru utilizarea unor metode complementare de culegere și analiză a informațiilor. Concret, am constituit, prin arhivarea personală a materialului lingvistic, un corpus complex, cu ajutorul a trei motoare de căutare și indexare specializate pentru a oferi rezultate selectate din știri și revista presei (ZiareLive.ro, versiunea oficială locală a Google News, respectiv Yahoo News). Prin introducerea cuvintelorcheie (coronavirus, Covid, Covid-19) au fost identificate 50.459 de articole cu ajutorul primului motor de căutare, dar menționăm că arhiva digitală limitează accesul la primele 10.000 de rezultate relevante, distribuite în cele 1000 de pagini web. Pentru a asigura acuratețea analizei calitative, aceste articole au fost revizuite și prelucrate manual, iar ulterior rezultatele au fost completate prin corelarea cu datele obținute din celelalte două platforme.

O dificultate deloc de neglijat a fost stabilirea particularităților distinctive ale structurilor uzate, care să legitimeze includerea lor în inventarul de clișee. Un element frecvent evidențiat în metadiscursul asupra clișeului îl constituie semnalarea dificultății de a se ajunge la un consens în formularea unei definiții exacte, pe baza unor caracteristici cuantificabile în mod obiectiv (Kirkpatrick, 1996; Hargraves, 2014).

În acest context, am considerat că se impune elaborarea unei definiţii de lucru suficient de riguroase pentru a clarifica nebuloasa terminologică și pentru a răspunde unor întrebări esențiale care ne-au alimentat demersul investigativ, ca de exemplu: Cum identificăm în mod științific un clișeu: prin apelul la intuiție, sensibilitate lingvistică sau există anumite trăsături clare de diferențiere? Care sînt parametrii intrinseci specifici structurilor clișeizate?

\subsection{Instrumente și concepte pentru identificarea și analiza clişeelor jurnalistice: analiza semică, izotopie lexico-semantică}

În ceea ce privește metodologia de analiză a corpusului adnotat, am pornit de la premisa că nu este suficientă abordarea intuitivă, bazată pe un anumit tip de sensibilitate lingvistică și pe reacția de déjà-vu, fiind esențial să operăm cu un set clar de reguli pentru identificarea automatismelor verbale.

Prin urmare, am examinat, prin filtrul analizei semice, definițiile și perspectivele asupra clișeului, extrase în urma incursiunii lexicografice și în bibliografia de specialitate?

Sintetizînd rezultatele investigației, relevăm semele dominante semnalate în definirea clișeului lingvistic: caracter prefabricat, entropie referențială, familiaritate, frecvență ridicată, grad variabil de uzură semantică, valoare funcțională (funcții fatice, pragmatice de facilitare a comunicării, de coeziune socială, de reducere a efortului cognitiv etc.). Desigur, aici se impune o discuție detaliată ${ }^{10}$ generată de constatarea

\footnotetext{
${ }^{9}$ Concret, adoptînd această perspectivă, am investigat trei categorii de definiții preluate din surse diferite pentru o privire de ansamblu, astfel: resurse lexicografice autohtone, străine (atît generale, cît și specializate: dicționare de lingvistică, tratate de stilistică etc.), respectiv, din literatura de profil (lucrări de referință ale unor cercetători care au studiat fenomenul stereotipiei: Ruth Amossy, Anne Herschberg-Pierrot, Patrick Imbert, Eric Partridge, Anne-Marie Perrin-Naffakh, Walter Redfern, Michael Riffaterre, Hargraves etc.).

${ }^{10} \mathrm{Am}$ ajuns la concluzia că nu putem susține cu argumente concludente că aceste particularități ar garanta în mod automat încadrarea unui lexem sau a unei structuri în categoria clișeelor. De exemplu, am observat că și alte criterii invocate, luate independent („parametrul singular al frecvenței unui element în discurs” (Nagy, 2016, p. 71), gradul de familiaritate, „,caracterul noncompozițional", specific unor clișee din clasa expresiilor idiomatice) nu constituie condiții indispensabile pentru clișeizare. În mod similar, o altă precauție în definirea clișeului ar fi evitarea extrapolării unor aspecte preconcepute conform cărora toate clișeele sînt structuri care „și-au pierdut impactul prin uzul constant” (Bagnall, 1985, p. 19). În acest sens, anumite clișee jurnalistice specifice jurnalismului tabloid infirmă această ipoteză, dacă avem în vedere numărul semnificativ al „consumatorilor” de
} 
că trăsăturile enumerate corespund și altor fapte lingvistice, de la interjecții la frazeologisme. Trebuie să avem în vedere faptul că stabilitatea semantică și sintactică nu reprezintă o garanție a clișeizării, în cazul în care aceasta este rezultatul „fixării prin consens” („frazeologemele întrunesc, de exemplu, consensul comunității lingvistice”), ci doar atunci cind are loc „uzura sensului prin repetiţie” (Duda, 2016, p. 21).

Pentru a evidenția rețelele semantice în care se „coagulează” clișeele circumscrise discursului mediatic al pandemiei de Covid-19, vom opera la nivel macrotextual cu conceptul de izotopie $e^{11}$, un instrument de analiză preluat din „recuzita” semanticii interpretative. Termen adoptat de A.J. Greimas în 1966 din domeniul fizicii, acesta „,desemnează modalitățile ce țin de structura și de organizarea nonlineară a textului și contribuie la coerența lui, avînd la bază redundanța unui element de semantică discursivă” (Nagy, 2015, p. 203), implicit sau explicit la nivel sintagmatic. Corpusul nostru ilustrează relațiile identificate între o serie de grupări lexico-semantice cu o organizare mai puțin riguroasă comparativ cu cea a cîmpurilor lexicale, pe care le vom analiza la nivel semic (componențial), contextual și stilistic (vezi modelul propus de Bidu-Vrănceanu \& Forăscu, 2008).

\section{Rezultatele și concluziile demersului investigativ}

\subsection{Automatismele jurnalistice generate de discursul mediatic al pandemiei. Particularități la nivel micro- textual}

La acest prim palier al analizei, am avut ca punct de pornire în organizarea corpusului criteriul extinderii formale propus de Dascălu-Jinga (2009). În acest sens, am identificat șabloane pe care le vom numi clișee monolexematice, clișee polilexematice (similare clișeelor-sintagmă din accepțiunea autoarei), respectiv, pentru secvențele prefabricate, mai elaboarate din punct de vedere lexico-sintactic, reținem formula lingvistei citate „clișee-enunț”. Vom urmări să demontăm valențele semantice noi pe care aceste structuri prefabricate le actualizează în discursul media, contextele specifice de utilizare și efectele în planul receptării. În esență, modelul pe care îl propunem în analiza clișeului valorifică principalele aspecte și unghiuri teoretice de abordare schițate în Fig. 2.

\subsubsection{Aspecte morfologice}

Din punct de vedere morfologic, în seria clișeelor monolexematice am observat o inflație de adjective calificative, cu o predilecție spre utilizarea abuzivă a superlativului absolut (amplu, alarmant, catastrofal, decisiv, dramatic, fabulos, fatal, halucinant, incendiar, magistral, major, radical, stupefiant, total, uluitor, viral etc.), urmate de ocurențele adverbiale. Interesant de semnalat este că am identificat un procent mai redus de clișee pe tiparul morfologic al substantivelor simple, utilizate pînă la desemantizare în jurnalismul tabloid (coşmar, colaps, cutremur, dezastru, dramă, şoc, fulger, război, măcel, tragedie etc.).

acest tip de presă care oferă un spațiu fertil automatismelor lingvistice. Din tendința de a generaliza pe baza unor clase de clişee și prin „filtrul” unei grile de interpretare, se poate ușor cădea în capcana unei definiții restrictive. Așadar, se impune subliniat faptul că trebuie să avem în vedere palierul lingvistic la care ne raportăm sau perspectiva de analiză în funcție de care putem identifica particularități ce țin de natura și diversitatea funcțională a clișeelor.

De exemplu, din unghiul microperspectivei date de analiza lexico-semantică, putem să identificăm particularități ale clișeului, aducînd în discuție o serie de aspecte precum restricția semantică, respectiv variabilitatea referențială, specifică unui grad avansat de clișeizare. Pe baza analizei semantice, se pot identifica două tipuri de clișee: pe de o parte, cele stabile din punct de vedere semantico-referențial (care vizează întotdeauna o clasă, o realitate specifică: aleși, baroni, oamenii legii, sportul rege etc. și suferă, prin urmare, o restricție semantică), iar pe de altă parte, clișee cu o variabilitate referențială accentuată, putînd fi aplicate unor realităţi diverse (colac de salvare, colaps, la indigo etc.). Dacă luăm, de exemplu, sintagma oamenii legii, observăm că aceasta este utilizată în discursul media pentru a individualiza, de regulă, clasa polițiștilor, mai rar a jandarmilor, excluzînd alte categorii profesionale congruente cu zona legislativului, în timp ce expresia clișeizată (tras) la indigo poate fi aplicată unui număr impresionant de referenți extrem de diferiți, cu valori axiologice predominant negative, peiorative (accident, atentat, crimă, cutremur, destine tragice, dosar penal, dramă, incident, jaf, mită, probleme, scandal, sinucidere).

${ }^{11}$ Conceptual, termenul desemnează un „ansamblu redundant de categorii semantice ce creează posibilitatea interpretării uniforme a discursului. Astfel, enunțul «Ce mai varză!» poate fi citit pe o izotopie culinară (mîncare reușită) sau pe o izotopie culturală (lucrare încîlcită, nereușită ca și «ghiveci»)" (Rovența-Frumușani, 1999, p. 295). 


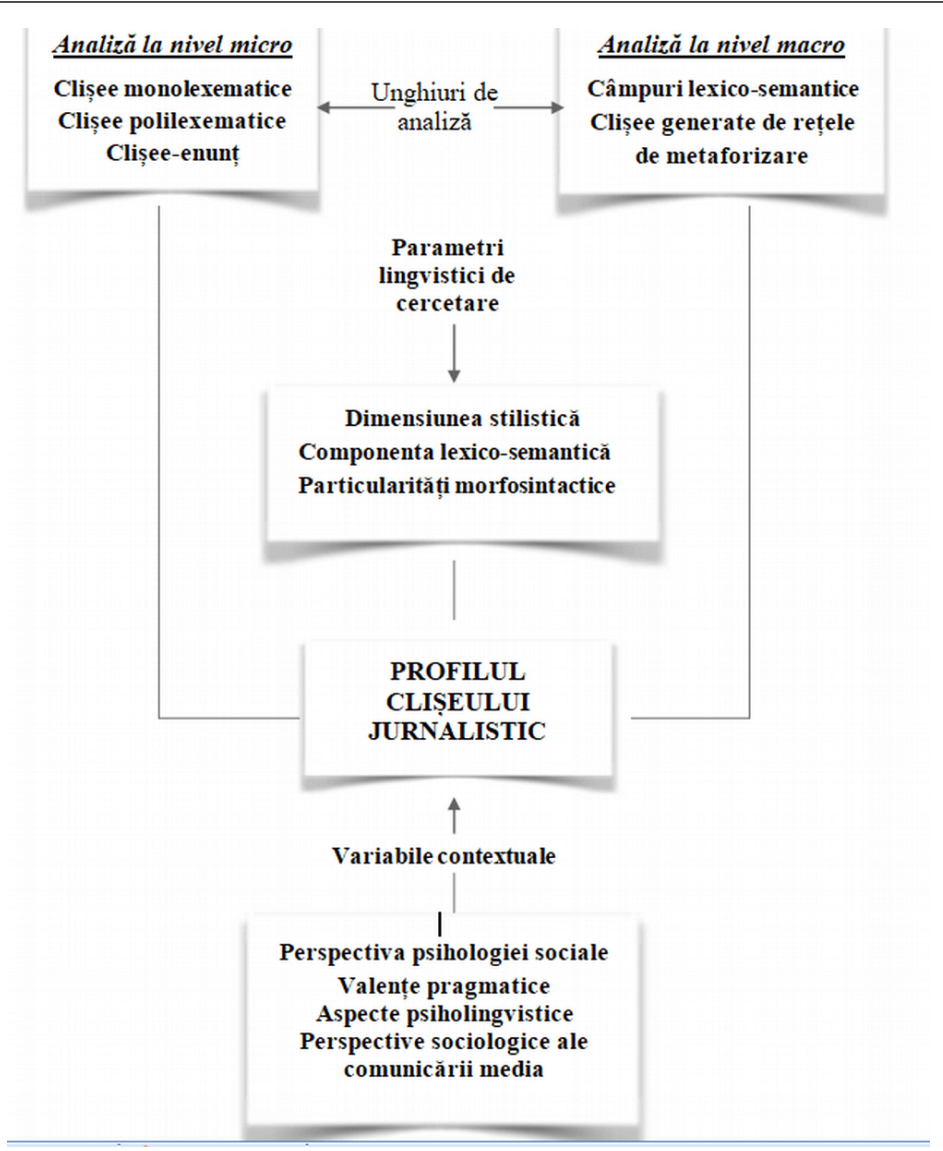

Figura 2: Model de cercetare elaborat pentru analiza clișeului jurnalistic

Clișeele polilexematice se „mulează”, de regulă, pe tiparul morfologic al grupurilor nominale, al locuțiunilor adjectivale și prepoziționale, în timp ce clișeele de tip enunț, cele mai persistente, prezintă un grad de familiaritate atît de ridicat, încît receptorii pot reconstitui enunțul din memorie, chiar imediat după ce văd primele elemente ale secvenței prefabricate. În Tabela 1 am selectat cîteva exemple relevante pentru categoriile discutate.

\begin{tabular}{|c|c|c|}
\hline Clișee monolexematice & Clișee polilexematice & Clișee-enunț \\
\hline $\begin{array}{l}\text { adjective calificative: } \\
\text { alarmantă }{ }^{12}, \text { catastrofal, } \\
\text { cutremurător }{ }^{13}, \text { crucial, } \\
\text { dramatic, fatal, halucinant, } \\
\text { incendiar, infernal, masiv, } \\
\text { radical, terifiant, uluitor, viral; } \\
\text { - substantive: coşmar, colaps, } \\
\text { cutremur, dezastru, dramă, soc, } \\
\text { fulger, război, măcel, tragedie } e^{14} \text {; }\end{array}$ & $\begin{array}{l}\text { - catastrofä națională, colac de } \\
\text { salvare, dezastru planetar }{ }^{15} \text {, } \\
\text { drama Covid-19 } 16 \text {, prioritate } \\
\text { zero, proporție covîrșitoare, } \\
\text { zi/noapte/săptămînă/clipel } \\
\text { scene/prognoză de coșmar, } \\
\text { imagini apocaliptice, } \\
\text { raport/scenariu pesimist; } \\
\text { - protest de amploare }{ }^{17}\end{array}$ & $\begin{array}{l}\text { - „Zeci de moldoveni au luat cu asalt laboratoarele } \\
\text { private din Capitală pentru a-și face testul la } \\
\text { COVID-19” (publika.md, } 3 \text { aug.); } \\
\text { - „Cazurile de Covid-19 cresc alarmant. Care este } \\
\text { explicația specialiștilor” (spynews.ro, } 5 \text { aug.); } \\
\text { - „Cazurile de Covid cresc alarmant: } 460 \text { de noi } \\
\text { îmbolnăviri” (ampress.ro, } 25 \text { iun.); } \\
\text { - „Coronavirusulpune pe jar întreaga comunitate } \\
\text { din Roșiești” (vremeanoua.ro, } 7 \text { aug.); }\end{array}$ \\
\hline
\end{tabular}

\footnotetext{
${ }^{12}$ „Creștere alarmantă a numărului de infectări Covid-19 în Hunedoara” (romania-actualitati.ro, 12 aug.); „Cifre alarmante! +474 de cazuri noi de infecție Covid și șase decese timp de o zi” (ziarelive.ro, 12 aug.); „Creștere alarmantă a numărului de infectări cu noul coronavirus în județul Hunedoara, unde s-au înregistrat peste 50 de noi cazuri” (romania-actualitati.ro, 12 aug.);

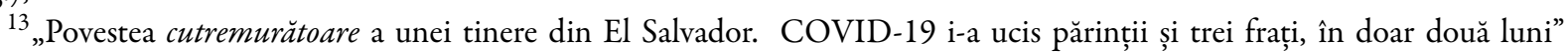
(libertatea.ro, 28 iul.);

${ }_{14}^{14}$ "Tragedie la Roma, unde o profesoară s-a sinucis crezînd că are coronavirus” (digi24.ro, 10 sept.);

${ }^{15}$ „Este dezastru planetar! Pandemia abia a început. Veste șoc pentru toată lumea” (capital.ro, 17 sept.);

${ }_{16}^{16}$,Drama Covid-19 abia urmează: Aproape 60 de milioane de joburi din UE, în pericol” (sputnik.md, 25 aug.);

${ }^{17}$ „Protest de AMPLOARE față de restricțiile Covid! Oamenii au ieșit în stradă” (dcnews.ro, 29 aug.);
} 
- verbe: a exploda, a cutremura, - focar de infecție/ al infecțiilor ${ }^{19}$; a crește, a stopa;

- adverbe: agresiv ${ }^{18}$, dur, ferm.
- focar de Covid-1920/ coronavirus;

- record absolut de cazuri Covid;

- fără margini ${ }^{21}$;

- de ultimă oră, la nivel inalt, pe deplin, pe fondul etc.
- „Covid revine in forță în Italia: 947 de cazuri de infectare au fost raportate în ultimele 24 de ore" (stiripesurse.ro, 21 aug.);

- „COVID-19 revine in forță! China înregistrează un vîrf de contaminări” (stiripesurse.ro, 29 iul.);

- "Covid-19 face ravagii” (capital.ro, 17 sept.);

- „COVID-19 a fácut prăpăd în întreaga lume” (stiripesursero, 16 iul.).

Tabela 1: Tipuri de clişee jurnalistice la nivel microtextual

\subsubsection{Aspecte stilistice}

Analiza sistematică a corpusului nostru relevă un comportament expresiv interesant al clișeului jurnalistic, în sensul în care își activează valențe dominante în funcție de un anumit domeniu. Concret, am înregistrat o densitate semnificativă de clișee metaforice, cu predilecție în domeniul politic, în timp ce hiperbola este, cu certitudine, clișeizată în domeniul sportiv, dar, în același timp, funcționează ca un indice de individualizare pentru jurnalismul de tip tabloid. Am constatat o tendință de exploatare a clișeelor formatate pe tiparul stilistic al antonomazei, pe care le vom examina în notele din tabel. Nu sînt deloc de neglijat ocurențele semnificative ale clișeului litotic în corpusul cu secvențe prefabricate generate de discursul pandemiei, dacă avem în vedere faptul că această valență stilistică este mai rar activată de jurnaliști. (De regulă, litota are un uz restrictiv, limitat la domeniul relatării evenimentor diplomatice). În Tabela 2, oferim o perspectivă de ansamblu asupra valențelor expressive dominante, activate de clișee ale pandemiei în discursul mediatic online.

Exemple de clișee în context

- „Nemții rup lanțurile Covid, românii își trag masca și pe ochi!” (national.ro, 2 aug.);

- „Puzzle-ul pandemiei COVID-19 în Africa: oamenii de știință nu-și pot explica absența unui vîrf epidemic" (adevarul.ro, 6 sept.);

- „COVID-19: mărturii din infernul alb” (perfecte.ro, 13 aug.).

- „Bubuie cazurile de COVID-19: Italia, pentru prima dată peste 1.000 după 15 mai” (stiripesurse.ro, 22 aug.);

- „ALARMANT! Bubuie cazurile COVID-19 în Spania înainte de începerea școlilor. Care este cel mai afectat oraș” (stiripesurse.ro, 8 sept.);

- „Covid-19 face ravagii și în Căminul de bătrîni Al. Marghiloman. Județul Buzău înregistrează un nou record de infecții cu noul coronavirus" (ziarelive.ro, 21 aug.);

- „Coronavirusul face ravagii! Cazuri noi, pe bandă rulantă. Medicii sînt în alertă” (capital.ro, 17 sept.);

- „COVID-19 a făcut prăpăd în întreaga lume - 579.938 de persoane au murit! Care sînt țările cele mai afectate” (stiripesurse.ro, 16 iul.);

- „COVID-ul face prăpăd în județul Vaslui: viceprimar luat cu izoleta, sucursală de bancă închisă! 30 de cazuri noi în ultimele 24 de ore!" (vremeanoua.ro, 7 aug.).
Valență stilistică, domeniu de utilizare

\section{Metaforă}

- Clișeul metaforic predomină în presa politică, sportivă, economică și în editoriale, „permeabile” subiectivismului și figurilor de stil.

\footnotetext{
Hiperbolă

- De regulă, clișeele hiperbolice au o arie de utilizare mai largă, simptomatice pentru jurnalismul tabloid, sportiv și, mai ales, în contextul evenimentelor meteo neobișnuite, a dezastrelor naturale (inundații, viituri, ninsori) sau a relatărilor despre accidente dramatice. Discursul mediatic al pandemiei de Covid-19 se distinge prin clișee hiperbolice, ale excesului dramatic, cu rolul de a augmenta o stare artificială de alarmă și panică.
}

\footnotetext{
${ }^{18}$ „COVID-19 se răspîndește agresiv printre tineri. OMS: Procentul celor infectați s-a triplat” (national.ro, 5 aug.);

19 „Italia, noul focar al infecțiilor cu COVID-19 din Europa. Zone de evitat. Ce recomandă specialiștii” (ziuaconstanta.ro, $24 \mathrm{feb}$.);

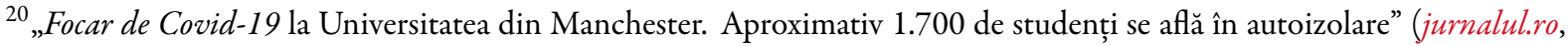
26 sept.);

${ }^{21}$ „Tragedie färă margini. Ministrul a fost ucis de covid-19” (playtech.ro, 29 iul.).
} 
- „Covid-ul a băgat SUA în șomaj. Aproape jumătate dintre americani nu au un loc de muncă din cauza pandemiei” (romaniatv.net, 30 iun.);

- „Mai nou, COVID-ul vine la Iași de peste Prut. Sîntem pe locul IV la nivel național” (ziaruldeiasi.ro, 11 sept.);

- „Coronavirusul bîntuie și în penitenciarele din țară. Cîți deținuți s-au îmbolnăvit de COVID-19" (publika.md, 25 aug.);

- „COVID-ul s-a furișat în Primărie! Se știa, dar institutia reacționază cu efect întîrziat!” (satmareanul.net, 2 aug.);

- „COVID-ul își face de cap! 9 cazuri noi la Satu Mare!” (satmareanul.net, 15 aug.);

- „Unde stă COVID-19 la hotel - studio” (business24.ro, 5 aug.).

- „În spitalul județean Botoșani s-a realizat un videoclip în care se cînta ca la nuntă într-unul din saloane. Mai mult, au postat pe Facebook cîntarea, să vadă ce veseli şi sănătoși sînt covizii” (adevarul.ro, $11 \mathrm{mai}$ );

- „Născută printre „covizi”! Viața își urmează cursul!” (ziarelive.ro, 22 iul.);

- „Patru marocani „covizi” fugiți din carantină” (evz.ro, 12 mai);

- „Infecționiștii de la Balș, între covizi, Salam, Bahmuțeanca și Pian” (evz.ro, 6 aug.);

- „Au căutat „COVIZI” și au dat peste hoți de lemne!” (jurnaldebacau.ro, 11 iul.).

\section{Personificare}

- De obicei, clișeul personificator înregistrează ocurențe semnificative în domeniul meteo, mai frecvent în reportajele televizuale, unde avem și formula consacrată de un cunoscut prezentator de televizune (Busu): „Vîntul va sufla nervos în majoritatea zonelor, iar la munte vor predomina ninsorile!” (tvhappy.ro, 6 oct. 2016), „Meteo: Zile reci, vînt nervos" (ziare.com, 21 apr. 2015). Clișeul personificator conduce, în cazul de față, la o antropomorfizare a pandemiei actuale.

\section{Antonomază $\breve{a n}^{22}$}

- Este interesant de semnalat evoluția semantică rapidă a lexemului covid de la stadiul de inovație jurnalistică, perceput ca ,una dintre cele mai frapante noutăți lexicale ale registrului colocvial din ultimele luni” (Zafiu, 2020) la etapa de clișeizare, prin intrarea în uzul comun. Acest tip aparte de antonomază, realizată prin ortografierea cu litere mici în locul majusculelor, reflectă o glisare semantică de la denumirea bolii la „persoane infectate cu acest virus". Se observă tendința ca forma lexicală marcată de morfemul de plural cu rol de generalizare să concureze varianta de substantiv la singular, articulat enclitic (Covidul/covidul_atît cu majusculă, cît și cu minusculă). Procesul de clișeizare este vizibil și în tendința jurnaliștilor de a renunța la ghilimele, ca marcator al efectului stilistic.

- „Alegătorii non-COVID, prioritari la votul cu urna mobilă” Litotă (infomures.ro, 25 sept.);

- „Spitalul Colentina, redeschis pentru pacienții non-COVID”

- De regulă, clișeul litotic este frecvent preluat de (, 31 aug.);

- „DSP: Spitalul Colentina asigură, de joi, asistență medicală și pacienților non-COVID-19” (digi24.ro, 16 iul.);

- „Urgențele medicale, chirurgicale și oncologice pe perioada pandemiei. Ce opțiuni au pacienții non-COVID?” (digi24.ro, 23 apr.);

- „Ce se întîmplă cu pacienții non-COVID în vremea pandemiei: Au murit oameni din cauză că pînă s-a intervenit pe accident vascular, i-au testat pentru coronavirus. A durat 7 ore" (hotnews.ro, $11 \mathrm{mai}$ );

- „Bolnavii non-COVID, ignorați și refuzați de spitale.

Definirea „urgențelor“ creează probleme de viață și de moarte” (adevarul.ro, 8 apr.). jurnaliști din limbajul diplomatic. În contextul relatărilor despre pandemia de coronavirus, figura de stil menționată mizează pe atenuarea posibilei stigmatizări asociate infectării cu virusul, prin negarea contrariului, pentru a-i indica pe cei care nu sînt bolnavi.

Tabela 2: Tabel sintetic cu valențe stilistice dominante activate de clișeele jurnalistice din discursul mediatic al pandemiei de Covid-19

\subsection{Particularități ale clișeului jurnalistic la nivel macrotextual}

Observarea, descrierea tiparelor dominante de clișeizare și interpretarea modului de conceptualizare a pandemiei de Covid-19 în discursul mediatic oglindesc, conform lingvisticii cognitive, conexiuni între

\footnotetext{
${ }^{22}$ „Figura semantică prin care un nume propriu-considerat reprezentativ pentru clasa respectivă-este utilizat în locul unui nume comun” (Stoichițoiu-Ichim, 2005, p. 75).
} 
gîndire, limbaj și acțiune. În corpusul de care dispunem, am constatat configurarea următoarelor izotopii lexico-semantice dominante și bine conturate, subsumabile următoarelor domenii: războiul, dezastre ale naturii cu aria lichidității, competiția sportivă, clasamentul și competiția sportivă etc. Constrîngerile de spațiu aferente acestui articol ne limitează la analiza nuanțată a primelor două izotopii.

\subsubsection{Covid-19 prin filtrul metaforelor din terminologia militară: izotopia războiului}

Dintre toate izotopiile lexico-semantice investigate la nivel macrotextual, cea configurată în jurul metaforei conceptuale a războiului este cel mai bine reprezentată în corpusul nostru. Coroborate cu aceste aspecte, o serie de întrebări ne-au orientat cercetarea și reflecțiile teoretice: Care sînt implicațiile și mizele clișeizării metaforelor militare? Putem vorbi în acest caz despre o percepție distorsionată a realității ?

$\mathrm{O}$ incursiune în bibliografia de specialitate relevă faptul că exploatarea metaforelor militare atît în discursul mediatic occidental, cît și în cel asiatic, a constituit obiectul de investigație al multor cercetări, de regulă în raportările din domeniul medical, al cancerului ${ }^{23}$. Desigur, în contextul actual, au fost analizate şi în relație cu mediatizarea pandemiei de coronavirus (Craig, 2020; Al Husain, 2020; Yang, 2020; Olimat, 2020; Rafi, 2020; Rajandran, 2020).

Popularitatea metaforei războiului în discursul media poate fi justificată pe baza unui argument simplu: pe de o parte, războiul este un concept familiar, pe de altă parte, complexitatea acestui „fenomen multifaţetat" (Shimko, 1995, p. 79) permite o relaţionare cu aspecte diferite ale realităţii din perspectiva multiplelor dimensiuni înglobate. Jurnaliștii activează, așadar, prin metafora conceptuală ceea ce receptorii știu deja despre acest domeniu-sursă (războiul) și transferă aceste cunoștințe într-un domeniu de experiență nou, nefamiliar (domeniul-țintă: pandemia de Covid-19): inamicul devine pandemia, soldații „din prima linie”, eroii sînt medicii, armele sînt de natură diversă (purtatul măștii, măsuri de izolare și carantină, un posibil vaccin, interdicții de călătorie), cîmpul de luptă devine propriul corp uman, respectiv orașele, continentele, iar, la un alt nivel de interpretare, „corpul” societății. În același registru, victoria devine sinonimă cu oprirea răspîndirii virusului prin identificarea unei soluții (ceea ce lansează cursa vaccinurilor), infrîngerea se cuantifică zilnic prin numărul/rata infectărilor, a persoanelor depistate pozitiv, acutizarea crizei financiare, și, desigur, strategia de război inițiată de autorități se traduce prin măsurile de izolare, distanțare socială și carantină.

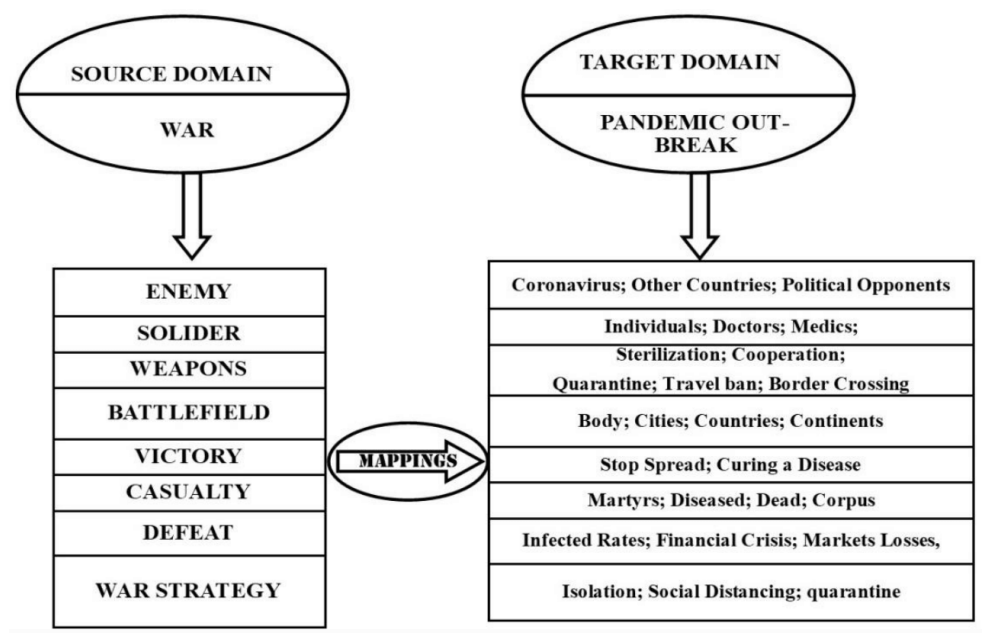

Figura 3: O reprezentare a schemei de metaforizare: Pandemia este un război. Sursă: Al Husain (2020, p. 119).

\footnotetext{
${ }^{23}$ Impactul retoricii războiului asupra tiparelor cognitive, sociale și comportamentale a fost sistematic examinat în lucrări de referință (Vaisrub, 1977; Sontag, 1978; Semino et al., 2017 etc.). Studiile recente au relevat implicațiile predominant negative ale metaforelor militare asupra sănătății și au propus personalului medical o reconceptualizare pe direcția coabitării, a călătoriei, a metaforelor alternative (a se vedea „meniul” metaforic propus de echipa de cercetători de la Universitatea Lancaster coordonată de Elena Semino [online]). Interesant, după acest model a fost recent lansată o iniţiativă de către specialiști în lingvistica cognitivă în vederea regîndirii abordării metaforice a pandemiei de Covid-19 [online].
} 
Un alt punct de consens în analizele dedicate acestui aspect îl constituie reliefarea consecințelor imediate în planul realității (Al Husain, 2020; Yang, 2020). Concret, utilizarea excesivă a retoricii războiului, cu predilecție a metaforelor militare de ofensivă, alimentează un discurs al terorii, anxietății, panicii, alarmei, generînd o percepție distorsionată, a unei realități dominate de violență:

"Modelling COVID-19 as ENEMY and human encounters with it as BATTLES resulted in the actualization of emergent conceptual structures, a rather aggressive perception of the world. Indeed, the semantic associative mappings of conceptual field (battle, weaponry, victory, casualties, conspiracies, etc.), may result in such aggressiveness of worldview, accelerating negative responses such as anxiety, fear and panic" (Al Husain, 2020, p. 110).

Am observat și în corpusul nostru persistența cu care se exploatează elemente și forme tehnice de organizare militară: frontul luptei, arme, obiecte tăioase, explozibili, echipamente de luptă, dar și resurse umane implicate, protagoniștii unui scenariu de război (eroi, victime, inamicul), raportări specifice („Practic, ieri, un singur ieșean a cîștigat bătălia cu infecția cu SARS CoV2", ziaruldeiasi.ro, 25 apr.). Efectele indezirabile ale modelării metaforice sînt, desigur, stimularea anxietății, amplificarea panicii, dar și a acțiunilor iraţionale:

„PLAN pe CINCI ANI de luptă cu COVID-19. Liderul OMS Europa produce un cutremur: Sigur că vaccinul nu-i va pune capăt!" (dcnews.ro, 14 sept.);

„Vaccinul împotriva COVID-19 a generat un adevărat război în lumea spionilor, atît China, cît și Rusia intensificîndu-şi eforturile pentru a fura secretele americanilor" (digi24.ro, 7 sept.);

„Eroii din prima linie - Infirmiera vindecată de Covid-19 care a donat de cinci ori plasmă pentru a-și salva pacienții” (stiripesurse.ro, 7 sept.);

„Consiliul Fiscal: Războiul cu COVID-19 este unul de uzură, dar economia își revine” (europalibera.org, 1 sept.);

„Spania se află din nou într-o situație critică, după ce a înregistrat primul asalt al epidemiei de COVID19" (tvr.ro, 12 aug.);

„Vești bune de pe frontul Covid-19: focarele din două spitale din Timiş au fost închise de medici” (stiripesursero, 3 aug.);

"Şi, totuşi, vești bune pe frontul luptei anti-COVID: Salvatorii de la Detaşamentul de pompieri din Cîmpina au revenit la serviciu!" (ziarulprahova.ro, 25 iul.);

„Lupta cu pandemia de COVID: Cadre medicale nevoite să stea și 12 ore în combinezoane, unele au leșinat" (botosaneanul.ro, 31 iul.);

"Cîți buzoieni se luptă cu COVID 19 în acest moment" (opiniabuzau.ro, 10 aug.);

„Noi echipamente de luptă împotriva COVID-19 vor intra în dotarea Ambulatoriului Spitalului Județean de Urgență Cluj” (turdanews.net, 29 iul.);

„Spitalul Clinic Județean Mureș rămîne în prima linie de luptă împotriva COVID-19” (infomures.ro, 26 aug.);

„Victimele dezinformării despre COVID-19. Au murit după ce au băut urină de vacă și cămilă” (playtech.ro, 11 aug.).

Am observat că, la nivelul selecției lexicale, tiparul de clișeizare predilect îl constituie structura compusă din lexemul război și determinantul adjectival cu valoare de superlativ absolut (fără precedent, total). Această particularitate din fizionomia lingvistică a clișeului amintește de „blestemul superlativelor”, tipic limbii de lemn (Thom, 1993, p. 76):

„Război fără precedent în lumea spionilor. Miza: secretele vaccinului pentru COVID-19” (digi24.ro, 7 sept.); 
„Război total între Raed Arafat și Victor Costache! Unde voiau fiecare să ducă pacienții COVID-19” (capital.ro, 27 mart.);

„Război total între SUA și China. Acuzaţii extrem de grave aduse Partidul Comunist Chinez” (evz.ro, 22 apr.);

„Firea, în război total cu DSP București și ministerul Sănătății. Acuzaţii explozive” (evz.ro, 11 iun.).

\subsubsection{Aspecte frecvent activate din domeniul-sursă al războiului}

Elemente pirotehnice/explozibili. În mod predictibil, jurnaliștii activează din domeniul războiului și diferite elemente de muniție și explozibil, cu predilecție în domeniul politic și sportiv pentru a caracteriza o situație tensionată. Pasiunea jurnalistică pentru paradigma verbală a exploziei se reflectă și la nivel frazeologic prin exploatarea expresiei a arunca în aer. Corpusul de care dispunem relevă un grad accentuat de clișeizare în cazul acestei formule prefabricate. Pe baza numeroaselor exemple observate, se poate constata cu ușurință că discursul mediatic impune activarea unui sens diferit de cel denotativ, înregistrat în dicționare („a distruge ceva cu ajutorul unui exploziv”). În mod concret, clișeizarea se manifestă prin utilizarea în situații frecvente a sensului figurat dominant, așa cum l-am putut deduce pe baza analizei sistematice a exemplelor: „provocarea unei situații tensionate, dificile, prin acțiunile controversate ale unor politicieni, jurnaliști, persoane mondene”, cu potențiale efecte îngrijorătoare pentru viitorul țării, al politicii sau al altor domenii de activitate. La nivel psiholingvistic, preferința jurnaliștilor pentru utilizarea sintagmei a arunca în aer, în relație cu referenți abstracți sau concreți, derivă din prejudecata acestora în existența unor lexeme cu impact asupra receptorilor, care le garantează creșterea audienței. Cel mai adesea, tiparele de utilizare ale expresiei evidențiază o clișeizare la nivel semantic prin impunerea unor sensuri figurate specifice, dintre care evidențiem următoarele valențe dominante:

- a contesta, a desființa, a denunța (o teorie, un program, o instituție, legi, măsuri etc.):

„Universitatea Oxford aruncă totul în aer: «Numărul morților din cauza Covid-19 ar fi supraestimat»” (stiripesurse.ro, 17 iul.);

„China a descifrat genomul noului coronavirus. Descoperirea care aruncă în aer toate teoriile despre Covid-19. S-a aflat cine a răspîndit virusul!” (gandul.ro, 19 iun.);

„Cea mai recentă descoperire despre Sars-CoV-2 aruncă în aer tot ceea ce se știa pînă acum” (evz.ro, 8 aug.);

„Chinezii dinamitează Europa! Scandalul care aruncă în aer toată scena internațională” (capital.ro, 21 sept.);

„Informaţia care aruncă totul în aer: Coronavirusul a fost o alarmă falsă globală” (capital.ro, 12 iun.).

Noua valență semantică în acest caz apare, în mod explicit, în șapoul articolului ilustrat în exemplul anterior: „Un document intern de 93 de pagini întocmit de mai mulți experţi medicali externi, la comanda Ministerului de Interne de la Berlin, denunţă măsurile adoptate de autoritățile germane împotriva noului coronavirus" (capital.ro, 12 iun.).

- „a provoca sau accentua un scandal ca urmare a divulgării unor informații, documente controversate”:

„Coronavirusul și morții. Dezvăluirea care aruncă în aer România! Care e adevărul?” (evz.ro, 5 mai);

„COVID-19 aruncă în aer anul electoral. Paradox electoral: organizarea alegerilor locale la termen misiune imposibilă. Amînarea lor - o aventură” (jurnalul.ro, 6 apr.).

Tot din sfera elementelor pirotehnice, semnalăm ocurențele unei forme verbale cu un coeficient ridicat de clișeizare: a exploda. De regulă, în majoritatea contextelor în care este integrat acest automatism jurnalistic, conotațiile sînt dominant peiorative, cu sensul de „creștere exponențială a numărului de cazuri de infectări cu noul coronavirus” sau „proliferarea unei activităţi ilegale”. Forma verbală atinge un grad avansat de clișeizare, dacă avem în vedere variabilitatea referențială și diversitatea apreciabilă a naturii cauzelor generatoare de „explozie”, de la infectările cu noul coronavirus, pînă la traficul de stupefiante: 
„Infectările cu noul coronavirus explodează din nou. România depășește pragul de 1.300 de cazuri de COVID-19, un nou record în 24 de ore" (digi24.ro, 30 iul.);

„Rata de reproducere a virusului a explodat în Germania, după apariția focarului de la abatorul cu mii de angajați români” (ziarelive.ro, 22 iun.);

„Specialist Europol: Traficul de stupefiante a explodat în perioada pandemiei de coronavirus" (puterea.ro, 7 sept.).

Totuși, semnalăm și cazuri, în contextul relaxării măsurilor, în care clișeul dobîndește valențe neutre sau meliorative, cu predilecție în domeniul economic: „de a obține profit imediat”:

„Britanicii cumpără Dacia pe bandă rulantă! Vînzările au EXPLODAT în luna iulie: creștere cu 77,02\% faţă de perioada similară din 2019” (stiripesurse.ro, 5 aug.);

"Vìnzările de diamante au explodat din cauza carantinei de coronavirus" (forbes.ro, 26 apr.);

La nivelul selecției lexicale, tiparul de clișeizare predilect îl constituie structura formatată pe șablonul morfosintactic explozie + de + grup nominal ${ }^{24}$, integrată, de regulă, în contexte negative, perceptibile în determinanții explicativi (explozie de cazuri Covid-19/de Covid-19/a pieței de vaccinuri false/de infectări/a numărului de bolnavi etc.).

„Spania: Explozie de cazuri COVID-19 după prima săptămînă de școală” (radioiasi.ro, 13 sept.);

„Explozie de COVID-19 la loturile olimpice de judo: 17 sportivi, 3 oameni din staff-ul tehnic, plus secretarul general!" (gsp.ro, 23 sept.);

„Europol anticipează o explozie a pieței de vaccinuri false împotriva COVID-19” (agerpres.ro, 18 mai);

„Din nou explozie de cazuri noi de coronavirus în județul Suceava. Încă 123 de suceveni sînt confirmați cu noul Covid-19" (svnews.ro, 21 apr.);

„Cu o nouă explozie de cazuri, Rusia a ajuns epicentrul pandemiei de Covid-19. De ce are însă o mortalitate atît de mică?" (libertatea.ro, 8 mai);

„Explozie de infecții cu COVID-19. Ce înseamnă Scenariul 3 și cum te afectează” (realitatea.net, 14 mart.);

„COVID 19: Din nou explozie de infectări cu coronavirus în ultimele 24 de ore” (opiniabuzau.ro, 15 aug.);

„Explozie de cazuri Covid-19 în Germania” (stiripesurse.ro, 12 aug.).

Importat din aceeaşi terminologie a războiului, lexemul bombă se bucură de o popularitate remarcabilă în discursul mediatic online, procesul de clișeizare realizîndu-se contextual, în cadrul unor sintagme nominale cu grade diferite de uzură, de obicei derivate de la modelul prototipic știre bombă. Precedat de elemente nominale precum: declarație, discuție, informație, mutare, scenariu, clișeul lexical bombă activează conotaţia de „știre senzațională” și este utilizat excesiv, pînă la desemantizare. Utilizarea exagerată a acestui clișeu jurnalistic poate fi explicată dacă luăm în calcul cîteva argumente de ordin pragmastilistic și psiholingvistic. Prin urmare, la baza automatismului, stă tendința jurnalistului de hiperbolizare și producere a efectului de surpriză și a senzaționalului, prin orice tip de artificiu menit să capteze în mod ostentativ atenția receptorilor. Am remarcat faptul că, datorită impactului și a potențialului de captatio benevolentia, acest clișeu este exploatat cu predilecție în elementele peritextuale (îndeosebi în titlu, șapou), opțiune strategică, dacă avem în vedere rolul pivotal pe care acesta îl joacă în arhitectura textului jurnalistic:

\footnotetext{
${ }^{24} \mathrm{Am}$ constatat că multe dintre aceste șabloane rezultă din traducerea unor articole publicate în presa internațională, reflectînd astfel presiunea modelului mediatic occidental asupra discursului jurnalistic autohton. Și în acest caz avem un șablon cu circulație internațională: engl. explosion of Covid-19; fr. explosion de Covid-19; germ. Explosion von Covid-19.
} 
„Pentru Roland Barthes, titlul, sub «imperiul semnelor» este un enunț «metalingvistic»cu funcție «aperitivă », ceea ce înseamnă că trebuie să-i provoace cititorului pofta de lectură, strategie care se înrudește cu suspansul. Textul fiind o «marfă », oferirea sa este precedată de un «boniment» sau un «appetizer»" (Dumistrăcel, 2006, p. 16).

Atît în mediul online, cît și în discursul televizual, semnalăm o tendinţă de utilizare excesivă a lexemului bombă alături de alte clișee ale efectului de alertă, urgență, întotdeauna în poziție inițială, desegmentat grafic de restul mesajului prin semnul exclamării. De altfel, acest semn de punctuație este folosit strategic de jurnalist pentru a impune o pauză cu efect scontat, dacă ne gîndim la refocalizarea și reținerea atenției receptorilor în zona informației ostentativ semnalate. Prin urmare, clișeul devine o marcă verbală a jurnalismului tabloid, de senzație, perceptibil și în presa locală, cu ocurențe persistente și în discursul publicistic „serios”:

„Anunț-bombă! Vaccinarea anti-Sars-CoV-2, cu o singură doză, începe de astăzi. 60.000 de voluntari vor fi testaţi” (evz.ro, 24 sept.);

„Anunț-bombă de la Oxford! E vorba de vaccinul experimental anti-Covid” (evz.ro, 12 sept.);

„Demisie-bombă! Ministrul Sănătății a demisionat în plină pandemie” (evz.ro, 21 sept.).

Dacă „demontăm” din punct de vedere morfosintactic acest mecanism interesant de formare a structurii clișeizate, constatăm tiparul substantiv (S1), centrul grupului nominal - substantiv (S2), cu formă calificativă, subordonat prin poziția sintactică de atribut, configurație care i-a asigurat în literatura de specialitate fie denumirea de substantive adjectivizate sau „nume-epitet” (Stoichițoiu-Ichim, 2006, p. 239), fie formula de „substantive-atribut” (Barbu, 2012, p. 153). Dincolo de faptul că această combinație lexicală a reușit să suscite numeroase scenarii interpretative controversate, observăm că ambele substantive au ca particularitate distinctivă utilizarea lor în formă nearticulată. Este interesant de reținut faptul că acest tipar prefabricat a dobîndit statutul de clișeu și a cunoscut o evoluție semnificativă încă din perioada interbelică, iniţial în discursul mediatic sportiv, ulterior fiind preluat și adaptat contextului politic. De altfel, acest tipar eliptic s-a dovedit a fi versatil și extrem de productiv, generînd în discursul mediatic online numeroase variante precum declarații-cutremur, declarații-şoc, sentință-taifun, fiind de regulă exploatat potențialul în exprimarea „valorilor lexicalizate de superlativ” (Stoichițoiu-Ichim, 2006, p. 245).

Constatăm că, pentru a caracteriza o situație gravă, iminentă, jurnalistul extinde clișeul monolexematic bombă la expresia sintagmatică bombă cu ceas (engl. Covid-19 bomb). Următorul grupaj de exemple surprinde această tranziție:

„Bomba care stă să explodeze la Țăndărei. Comitetul Județean pentru Situații de Urgență propune carantinarea oraşului cu 4 decese din cauza COVID-19" (adevarul.ro, 2 apr.);

„Bomba de la Pașcani: 14 cadre medicale și 10 pacienți confirmați cu COVID-19” (ziaruldeiasi.ro, 25 apr.);

„Bomba cu ceas, după cele trei cazuri noi de COVID 19 de la „Municipal”: Nimeni nu este acasă, în izolare la domiciliu. Niciun contact direct" (pressalert.ro, 10 apr.);

„Bomba cu ceas care stă să explodeze în școlile din România” (mediafax.ro, 25 sept.).

Mijloace tehnice de luptă: arme, obiecte tăioase. Analiza numeroaselor tipare clişeizate din corpus relevă o variabilitate inedită a tehnicii de luptă și „armelor” împotriva virusului, de la proprietăți ale mediului (umiditatea din aer), instrumente terapeutice (bipnoză), măsuri de protecție recomandate oficial (purtarea măștilor de protecție in public), dispozitive inovative pentru sterilizare (lämpile cu ultraviolete), pînă la substanțe hormonale (progesteronul): 
„Studiu: Umiditatea din aer, o armă împotriva COVID-19” (stirileprotv.ro, 22 aug.);

„Românii iau cu asalt cabinetele de psihoterapie. Hipnoza, noua armă contra pandemiei” (evz.ro, 23 aug.);

„Purtarea măștilor de protecție în public - „arma secretă” care a ajutat Japonia să țină coronavirusul sub control" (digi24.ro, 7 iun.);

„Armele împotriva COVID și a altor bacterii sînt lămpile cu ultraviolete!” (profit.ro, 13 iul.);

„Progesteronul, „arma secretă” împotriva Covid 19? Ipoteza cercetătorilor americani despre hormonul sexual feminin" (mediafax.ro, 27 apr.).

La acest nivel, dintre tiparele morfosintactice recurente din corpusul nostru, se detașează următorul șablon lingvistic: armă + atribut adjectival (adjectiv calificativ cu funcția de a indica unghiul de exploatare al pandemiei, de regulă, în contul intereselor și agendelor politice, electorale, propagandistice etc.):

"Covid-19, armă electorală și în Israel” (mediafax.ro, 18 feb.);

„COVID-19 - arma propagandistică a Rusiei și Chinei” (europalibera.org, 6 apr.);

„SUA, proces pentru China. COVID-19, ARMĂ biologică împotriva omenirii. DAUNE și acuzații GRAVE” (dcnews.ro, 30 mart.);

„Virusul ucigaș, o armă biologică? Zeci de milioane de morți și haos în spitalele din lumea întreagă” (capital.ro, 27 ian.);

"Covid-19, armă electorală la Roșiești” (vremeanoua.ro, 12 aug.);

„Sabia Covid-19. Fabricarea armelor biologice nu a fost niciodată mai ușoară” (evz.ro, 8 sept.).

\subsubsection{Structuri specifice discursului de raportare al războiului}

O altă particularitate a clișeelor generate de această izotopie derivă din registrul discursiv al relatărilor despre conflicte armate:

„Pandemia de coronavirus s-a soldat cu cel putin 526.663 de decese în întreaga lume de cînd biroul din China al Organizației Mondiale a Sănătății a anunțat aparitia virusului, la sfarsitul lunii decembrie, și pînă astăzi, la ora 11.00 GMT (14.00 ora României), conform unui bilanț anuntat de AFP, notează News.ro" (stiripesurse.ro, 4 aug.);

„A treia familie decimată de Covid 19, în mai puțin de o lună” (bzb.ro, 17 sept.);

„FCSB, atacată de COVID-19 pe toate flancurile. Încă cinci jucători infectați. Meciul cu Backa Topola, sub semnul întrebării" (impact.ro, 17 sept.);

„Trump scoate artileria grea impotriva pandemiei COVID-19: a fost lansat proiectul «Operation Warp Speed», pentru accelerarea dezvoltării unui vaccin” ( $z$ f.ro, 30 apr.);

"Congresul american scoate artileria grea impotriva COVID-19: Aproape 500 de miliarde de dolari vor merge către spitalele din SUA" (zf.ro, 24 apr.).

Simptomatice pentru jurnalismul tabloid, structurile verbale formatate pe tiparul semantic al explozibililor ating un grad de clizeizare semnficativ, iar ocurențele actualizează valențe conotative. În corpusul investigat, ne-a atras atenția o sintagmă verbală interesantă, recent clișeizată, uneori evidențiată grafic prin utilizarea majusculelor pentru întregul nucleu frazeologic „a detona nucleara serii”, probabil ca alternativă sinonimică pentru un alt șablon jurnalistic intens utilizat „a arunca bomba”.

În unele cazuri, sesizăm o acumulare de clișee din lanțul metaforic al explozibililor, exploatată în cadrul titlului, din dorința jurnalistului de a completa la nivel semantic și vizual efectul de informație „explozivă”, în sensul unei dezvăluiri spectaculoase, de impact pentru public: 
„Medicii aruncă bomba! Un nou simptom pentru coronavirus. Ce s-a observat la pacienţii cu Covid-19” (national.ro, 17 iul.);

„Exclusiv. Un legist aruncă bomba. Ce nu apare în raportările zilnice legate de COVID-19” (evz.ro, 4 mai);

„Raed Arafat detonează bomba: Nimeni nu vorbește despre asta! Situația a devenit critică” (capital.ro, 4 iul.);

„Bombă: Arafat detonează nucleara serii! Serviciile sînt în alertă maximă” (capital.ro, 19 mai);

„Rareș Bogdan detonează bomba în privința coronavirus: Nu mai e loc și timp de analize” (capital.ro, 18 mart.).

\subsubsection{Aria lexico-semantică a fenomenelor și dezastrelor naturii}

De regulă, această tendință a discursului mediatic de a pune adesea în analogie fenomene naturale extreme (cutremur, furtună, incendiu, intemperii, inundații, secetă) „,cu situații de turbulență, de tulburare socială” (Bărîcă, 2009, p. 47) a fost semnalată în studii anterioare și în spațiul public englez sau sîrb (Kilyeny \& Silaški apud Duda, 2016, p. 153). Într-un articol relevant în acest sens, Semantica dezastrului, Duda (2010, p. 162) atrage atenția asupra ponderii semnificative a termenilor din cîmpul lexical al „nenorocirilor majore” în discursul jurnalistic de relatare, simptomatic pentru „tratamentul în cheie melodramatică a evenimentelor selectate”, în structura căruia identifică „termenii hiperonimici generici: calamitate, cataclism, catastrofă, dezastru, flagel, urgie față de care avalanșă, cutremur/seism, tsunami, uragan, viitură sînt termeni hiponimici, specifici".

\subsubsection{Izotopia lichidității: clişee modelate pe tiparul „metaforei hidrologice”. Tipare morfosintactice și particularități stilistice}

Vom nuanța analiza automatismelor jurnalistice pe tipar hidrologic, avînd în vedere o recontextualizare mai largă și includerea acestora în izotopia lichidității, un cadru mediatic (media frame) activat în mod recurent pentru a se „filtra” interpretările dominante ale pandemiei actuale.

În cercetările lingvistice anterioare s-a punctat preferința jurnaliștilor pentru utilizarea „metaforelor din domeniul lichidităţii” (Chifane, 2013, p. 89), în special pentru a caracteriza perioade de criză economică („economia se scufundă”). În zona semantică a meteorologiei, semnalăm recurența combinațiilor lexicale modelate pe matricea metaforelor hidrologice (vezi Bărîcă, 2009, p. 49), de regulă cu un grad de frecvență relativ ridicat în domeniul politic și monden. Am observat în investigațiile noastre anterioare că metaforele pluviale actualizează în majoritatea cazurilor conotaţii negative (ploaie de avertismente/de infracțiuni/de amenzi, potopul declarațiilor, șuvoi de acuzații, torent de acuzații, val de proteste/de agresiuni sexuale, viitură de politicieni) ${ }^{25}$.

În editorialele politice, permeabile subiectivismului jurnalistic, valențele axiologice ale clișeelor meteorologice antrenează, de regulă, semnificații negative, devalorizante. Rezultatele analizei relevă o pondere semnificativă în corpusul nostru a structurilor formatate pe șablonul morfosintactic avalanşă + de + grup

\footnotetext{
${ }^{25}$ În cercetările noastre lingvistice anterioare am semnalat și analizat o serie de clișee metaforice, create pe același tipar semantic al lichidității. De regulă, aceste automatisme apar în contexte marcate de convulsii sociale, politice, dintre care amintim proteste, imigrație, acte de terorism, evenimente sociopolitice majore (val de atentate/de imigranţi/de proteste, furtună de gloanțe, viitură de politicieni, ploaie de infracțiuni, furtună economică, potopul, tornada financiară declanșată de Brexit etc.). Reținem aici doar cîteva exemple sugestive:

„Val de atentate la Paris” (ziuaconstanta.ro, 16 iul. 2016);

„Furtună de gloanțe asupra oamenilor” (ziuaconstanta.ro, 16 iul. 2016);

„Hackerii de la Anonymous au declarat «război total» jihadiștilor de la Statul Islamic după valul sîngeros de atentate de vineri seara din Paris" (ziare.com, 17 nov. 2015);

„BREXIT: Inundațiile au făcut prăpăd, alegătorii înoată spre secțiile de vot” (ziare.com, 23 iun. 2016);

„UPDATE/Europa încearcă să-și revină după furtuna declanșată de Brexit. Puternicii Europei se întîlnesc la Berlin” (evz.ro, 27 iun. 2016).
} 
nominal, integrate, de regulă, în contexte negative, perceptibile în determinanții explicativi (avalanșă de noi cazuri de Covid-19/de cazuri pozitive/de bolnavi cu COVID-19/de schimbări legislativel de plingeri etc.). Am ilustrat prin grupaje de exemple reprezentative astfel de automatisme jurnalistice:

„ALERTĂ LA BÎRLAD: focar de COVID la Maternitate, directorul, dar și mai multe cadre medicale infectate, avalanșă de cazuri pozitive!" (vremeanoua.ro, 19 iul.);

„Medicii din Spania se străduiesc să stăvilească avalanșa de noi cazuri de Covid-19: ce sarcină nouă au primit" (stiripesursero, 28 iul.);

„Avalanșa de cazuri de Covid din ultima perioadă a scos din uz tomograful de la UPU. Se fac și cîte 50 de investigații într-o tură de 8 ore, față de 3-4 înainte de pandemie" (obiectivdesuceava.ro, 18 sept.);

"Ghid de navigare în avalanșa de schimbări legislative în contextul COVID-19” (business24.ro, 31 mart.); „Luată prin surprindere de avalanșa de bolnavi cu COVID-19, Spania declară război fumatului: ce propun medicii Guvernului" (stiripesurse.ro, 31 iul.);

„Politicieni și cetățeni care se tem de termometru au depus o avalanșă de plîngeri la Avocatul Poporului. Se cere sesizarea CCR" (digi24.ro, 22 mai).

Rămînînd în cîmpul fenomenelor meteo, sesizăm o variație semantică interesantă în tiparul metaforelor clișeizate, prin exploatarea categoriei intensității care mizează pe marca semantică / +forță/ (val, ploaie, potop, furtună, tsunami).

„Redeschiderea școlilor ar aduce un al doilea val de COVID-19! Ce spun cercetătorii?” (monitorulcj.ro, 4 aug.);

„Germania se confruntă cu al doilea val de Covid-19" (gds.ro, 4 aug.);

„Austria este lovită de al doilea val de COVID, a anunțat cancelarul Kurz. Guvernul a decis înăsprirea restricțiilor” (digi24.ro, 13 sept.);

„Marea Britanie s-ar putea confrunta cu un nou val de COVID dacă școlile se redeschid și testarea nu se extinde, potrivit cercetătorilor" (digi24.ro, 4 aug.);

„De ce nu are sens să vorbim de un al doilea val al pandemiei COVID-19. Ce spune OMS” (adevarul.ro, 29 iul.);

„Val de imbolnăviri de COVID 19, la Huși: prin Primărie, instituții publice și societăți comerciale crește numărul pacienților!" (vremeanoua.ro, 28 iul.);

„Val de controale anti-Covid în piețe, pe terase și în magazine” (monitorulbt.ro, 21 sept.);

„Angajatorii nu respectă măsurile de prevenție anti-COVID-19. Val de amenzi aplicate de Inspecția Muncii” (capital.ro, 14 sept.);

„Valul infecției cu COVID-19 lovește în Primăria Roșiești. Sediul instituției, dezinfectat” (vremeanoua.ro, 7 aug.);

„Val de confirmări, în ultimele 24 de ore! 41 de buzoieni depistaţi cu coronavirus! Situație critică în spitale" (jurnaluldebuzau.ro, 28 iul.);

„Bilanț COVID-19, 30 august! Pandemia continuă să facă ravagii în Romînia. Nou val de infectări” (capital.ro, 30 aug.);

„Toamna aduce un nou val de restricții anti-COVID. Țările europene care au înăsprit măsurile pentru a limita răspîndirea coronavirusului" (digi24.ro, 12 sept.);

„Nou val de decese cauzate de COVID-19: 45 de persoane au murit în ultima zi” (stiridecluj.ro, 18 aug.). 
* ploaie

„«Ploaie» de amenzi pentru nerespectarea stării de alertă! Peste 400 de persoane au fost sancționate într-o zi" (stiridecluj.ro, 21 iun.);

„Ploaie de sancțiuni în toată țara” (cotidianul.ro, 8 aug.);

„După ploaia de amenzi, urmează ploaia de procese: Românii au început să conteste în instanţă măsurile de carantină și izolare" (zf.ro, 30 iul.).

\section{potop}

"Coronavirus. Ciolacu, potop de acuzații: «Amenzi date la grămadă, după bunul plac!»” (evz.ro, 30 apr.);

„Potop de amenzi aplicate pentru nerespectarea măsurilor privind prevenirea și combaterea efectelor pandemiei de COVID-19" (adevarul.ro, 14 aug.).

\section{* tsunami}

Catastrofele naturale, care exercită asupra comunității internaționale un impact emoțional amplificat prin mediatizarea intensă, influențează în mod semnificativ și repertoriul de metafore mediatice autohtone. În acest sens, ulterior tragediei de la începutul anului 2004 din Oceanul Indian, s-a înregistrat o proliferare spectaculoasă a ocurențelor termenului de origine japoneză tsunami. Clișeizarea se poate explica prin utilizarea exagerată a valenței metaforice, în special în articolele pe teme politice și economice (vezi Bărîcă, 2009, p. 46-47; Duda, 2016, p. 156) pentru a se referi la o situație de criză inevitabilă generată de un eveniment imprevizibil cu efecte devastatoare. Intensitatea emoțională încapsulată de această metaforă, potențialul de a mobiliza energiile afective ale unei mase eterogene de receptori reprezintă, cu siguranță, elemente care pot explica preferința jurnaliștilor pentru utilizarea abuzivă, pînă la clișeizare, a acestui lexem. Analiza sistematică a corpusului nostru relevă următoarele tipare distincte:

\section{- tsunami + prepoziţie + determinant substantival}

„«Tsunami» de bolnavi de Covid-19 la Londra; respectarea izolarii, pusă la grea încercare" (ziare.com, 26 mart.);

„Tsunami de cazuri Coronavirus. Semnal suprem de alarmă din partea medicilor” (evz.ro, 17 iul.);

„,Tara care ar putea fi lovită de un «tsunami de coronavirus». Fără apă, spitale și medicamente: doar 100 de teste pe zi și acuze de mușamalizare" (gsp.ro, 13 apr.);

„Spitalele din Londra, confruntate cu un «tsunami continuu» de bolnavi în stare gravă din cauza coronavirusului" (digi24.ro, 26 mart.);

"Situație alarmantă în 19 țări europene, unde a fost raportat un «tsunami» de noi cazuri de coronavirus" (digi24.ro, 18 aug.).

\section{- tsunami + articol genitival/ prepoziție + determinant substantival}

La nivel lexico-semantic, tiparul reține din sensul primar, denotativ, indexat în dicționar, semul lexical /+cantitate/ cu rolul de a amplifica dimensiunea și gravitatea consecințelor unei situații:

„New York Times: Un tsunami al concedierilor este pe cale să lovească Europa. Milioane de angajați riscă să își piardă locurile de muncă" (romaniatv.net, 25 aug.);

„Marea Britanie: «Un tsunami de disponibilizări»” (forbes.ro, 25 mai).

- tsunami + adjectiv calificativ (tipar recurent în domeniul economic, financiar și politic):

„Spania, în fața unui tsunami financiar în cazul neprelungirii programului de șomaj parțial” (zf.ro, 7 aug.); „Ne putem aștepta la un tsunami economic! Dan Voiculescu, scenariu exploziv” (capital.ro, 6 mart.). 
Automatismele jurnalistice analizate se bucură de o popularitate remarcabilă și în peisajul mediatic internaţional ${ }^{26}$. De altfel, am observat și în studii anterioare (cazul Brexit) tendinţa discursului mediatic autohton de a prelua mimetic anumite grile de interpretare cu impact la nivel internațional.

Acest model de cercetare ne-a ajutat să înțelegem și să explicăm persistența unor structuri clișeizate create pe tiparul metaforelor hidrologice, simptomatice pentru contexte marcate de convulsii sociale, politice (proteste, imigrație, acte de terorism, evenimente sociopolitice majore: „,val de atentate”, „ploaie de infracțiuni”, „val de proteste”, „val de imigranți”, „tsunami financiar” etc.). Preferința jurnaliștilor pentru aceste clişee ale lichidității poate fi interpretată prin schimbarea unghiului de analiză de la palierul lexicosemantic și punerea în relație cu macroperspectiva dată de paradigma constructivistă (cadre mediatice prin care sînt filtrate evenimentele, strategii specifice de priming, framing) și viziunea sociologică asupra societății actuale, jalonată de vectori ai globalizării și dinamismului, specifici așa-numitei modernități lichide (vezi Bauman, 2000).

Explicaţia pentru un asemenea comportament lingvistic poate fi decelată dacă avem în vedere interpretarea sociologilor asupra lumii moderne, definită din ce în ce mai frecvent prin dimensiunea duală a lichidității: pe de o parte, obsesia și fascinația contemporană a fluxului ca imagine a „flexibilității globale”, pe de altă parte, teama de fluiditate și haosul social („valurile de imigranți” etc.):

„The modern world, that sociologists increasingly characterize by its liquidity, is peculiarly fascinated by flow as an image of global flexibility. The more our world is economically and militarily interconnected, the more we fear social fluidity" (Turner, 2003, p. 8).

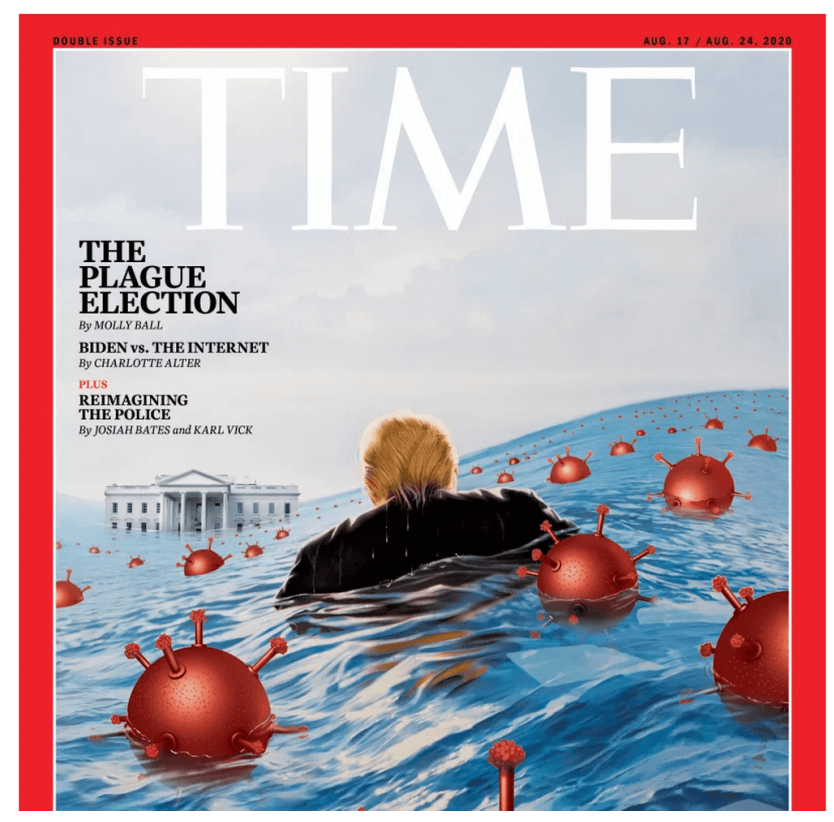

Figura 4: Sursă: libertatea.ro

Observăm o imagine relevantă pentru analiza de față, preluată din discursul internațional cu scopul de a „accesoriza” textul jurnalistic, probabil cu efectul de a amplifica coeficientul de dramatism, haos și la nivel iconic. „Pe noua copertă a revistei TIME, Trump înoată într-un ocean de COVID” (libertatea.ro, 8 aug.; Fig. 4).

\footnotetext{
26 "Tsunami of hotel closures is coming, experts warn" (LA Times via Yahoo Finance, 19 sept.);

"France is in midst of second wave and hospitals «at tipping point» warns A\&E union chief" (yahoo.com, 20 sept.);

"Rogue Oktoberfest parties could spark Covid second wave in Germany as cases hit highest since April, experts fear" (thesun.com, 21 sept.);

“Op-Ed: Could COVID-19 set off a wave of heart disease?" (latimes.com, 18 sept.).
} 
Aplicînd modelul nostru de cercetare am identificat o concentrare, o densitate semnificativă a clișeelor în cazurile frecvente de intersectare a discursului mediatic al pandemiei cu aria semantică a fenomenelor meteorologice. Această observație ne-a condus la ideea existenței unei strategii la nivel lexico-semantic de care jurnalistul uzează pentru a sugera, în subsidiar, prin acest transfer metaforic asupra naturalului devastator, incontrolabil, o lipsă de asumare a responsabilităţii, tipică autorităţilor, în cazul unor derapaje de natură economică, financiară, politică etc. Am explicat cum intensitatea emoțională încapsulată de aceste metafore ale dezastrului natural, potențialul de a mobiliza energiile afective ale unei mase eterogene de receptori constituie elemente care explică preferința jurnaliștilor pentru utilizarea abuzivă, pînă la clișeizare, a acestor lexeme.

\section{Observații și concluzii finale}

Analiza automatismelor lingvistice generate de abordarea pandemiei actuale în discursul jurnalistic online ne-a oferit indicii relevante, nu doar pentru a identifica particularități noi ale comportamentului lingvistic al clișeelor, ci și pentru înțelegerea mizelor, implicațiilor și posibilelor efecte ale clișeizării anumitor rețele semantice. În principiu, analiza acestor scheme de clișeizare dominante a relevat modul în care instanțele mediatice preiau, sub presiunea modelului internațional, izotopiile lexico-semantice care exploatează structuri prefabricate din domenii distincte: război, competiție sportivă și clasament, dezastre naturale, $\mathrm{cu}$ predilecție zona lichidității.

Care sînt, așadar, implicațiile și efectele exploatării mediatice ale acestor scheme de metaforizare generatoare de clișee?

Reflecțiile derivate din examinarea automatismelor lingvistice în relație cu pandemia actuală ne-au condus la sublinierea necesității de a decoda critic metaforele clișeizate de jurnaliști. Decurge, de aici, o interogație firească: în ce măsură putem susține că exploatarea acestor tipare lingvistice ne apropie periculos de acceptarea unor perspective radicale, distorsionate asupra realității sau de glisarea inconștientă pe versantul extremismelor (fie al consumului pasiv de informație care conduce, în timp, la anxietate și psihoză colectivă, fie al negării totale a realității)? De fapt, asemenea întrebări, dincolo de identificarea unui răspuns obiectiv, sunt esențiale pentru conștientizarea efectelor pe care le poate provoca utilizarea strategică a limbajului prefabricat. Aceste aspecte devin mai ușor perceptibile dacă admitem ideea că, de regulă, discursul mediatic (re)activează funcția constructivă, ideologică a clișeului de a oferi mai mult decît simple ,jaloane”, adevărate grile interpretative menite să substituie explicaţiile proprii, să „deturneze” căutarea sensului, prin „anestezia” gîndiri și inducerea artificială a unor stări emoționale intense.

În contextul infodemiei, efectele modelării metaforice pe tiparul războiului sau dezastrelor naturale și ale diseminării unor automatisme jurnalistice sunt, pe termen scurt: stimularea anxietăţii, a panicii și a acțiunilor iraționale, iar pe termen mediu și lung, amplificarea unui discurs al urii, al stigmatizării sociale și al prejudecăţilor antirasiste (a se vedea sintagma clișeizată „virusul chinezesc” atît în presa occidentală, cît și în cea autohtonă). Studiile existente pledează pentru promovarea limbajului neutru sau a schemelor de metaforizare alternative pentru conceptualizarea pandemiei actuale (a călătoriei, a coabitării etc.), recontextualizări care pot, de fapt, funcționa ca un „vaccin” la nivel mental și conceptual pentru a limita infectarea cu ceea ce am putea numi virus al fricii, al sentimentelor rasiste, prejudecăţilor şi stigmatizării: „act as a vaccine to control the spread of fear and racist feelings" (Rafi, 2020).

Rezultatele investigației au evidențiat că aceste șabloane lingvistice, analizate în „acolada” conceptuală a izotopiilor, pot funcționa ca strategii retorice și lexico-semantice. prin care jurnalistul activează energiile afective ale receptorilor. Astfel, se creează o realitate distorsionată și se întreține o stare artificială de neliniște, panică, anxietate. În timp, această operație, conduce, prin impactul repetiției obsesive, la consumul pasiv de reprezentări mediatice și stereotipuri culturale, idei preconcepute. Pe măsură ce sunt „sedimentate” în mentalul colectiv, aceste scheme-numite plastic de Bourdieu (2007, p. 44) „cultural fast-food”, sau „hrană pre-digerată, pre-gîndită”-pot modela ușor percepții, atitudini și reacții, inclusiv relații și procese în raport cu alteritatea la nivelul micro- sau al macrocomunității. 
Așadar, în contextul unei societăți a postadevărului și a dezinformării, dominată de consumul exponențial de informație falsă (fake news, infodemie), devine absolut esențială competența de a recunoaște și analiza, pe baza exercițiului lucid al gîndirii critice, funcțiile și valențele semantice, ideologice, culturale, activate de automatismele jurnalistice pentru o interpretare corectă și obiectivă a realităţii.

\section{Bibliografie}

Adam, M. (2020). An enemy to fight or someone to live with, how Covid-19 is metaphorically described in Indonesian media discourse, [online].

Al Husain, M.A. (2020). The Metaphorical Modeling of COVID-19 Pandemic Crisis in Infosphere Online News Articles, în "Journal of Education College", Wasit University, 1 (40), p. 655-672, Crossref.

Amossy, R. (2002). Introduction to the Study of Doxa, în „Poetics Today”, 23 (3), p. 369-394, Crossref.

Amossy, R. \& Herschberg-Pierrot, A. (2011). Stéréotypes et clichés: Langue, discours, société, Editions Armand Colin, Paris.

Amossy, R. \& Rosen, E. (1982). Les Discours du cliché, SEDES-CDU, Paris.

Arendt, H. (2006). Eichmann in Jerusalem: A Report on the Banality of Evil, Penguin Books, Londra (ed. I-a: 1964).

Bagnall, N. (1985). A Defence of Clichés, Constable \& Company Limited, London.

Barbu, A.-M. (2012). Construcțiile substantiv-substantiv, în „Studii și cercetări lingvistice”, 63 (2), p. 153-170.

Bărîcă, A. (2009). Metaforă și corporalitate în discursul media, Editura Paralela 45, Pitești.

Bauman, Z. (2000). Liquid Modernity, Polity Press, Cambridge.

Beciu, C. (2011). Sociologia comunicării și a spațiului public. Concepte, teme, analize, Editura Polirom, Iași.

Berger, L. (2011). Snapshots, or: Visual Culture’s Clichés, în „Photographies”, 4 (2), p. 175-190, Crossref.

Bidu-Vrănceanu, A. \& Forăscu, N. (2008). Modele de structurare semantică: cu aplicații la limba romînă: polisemie, sinonimie, antonimie, cîmpuri, Editura Facla, Timișoara.

Bourdieu, P. (2007). Despre televiziune, Editura Art, București.

Chelaru-Murăruș, O. (2007). Stereotipie și expresivitate: de la limba vorbită la textul poetic, Editura Universității din București, București.

Chifane, C. (2013). Metaphors Of The Crisis - A Reflection Of The Global Financial Situation, în „Management Strategies Journal", 22 (4), p. 78-84.

Craig, D. (2020). Pandemic and its metaphors: Sontag revisited in the COVID-19 era, în „European Journal of Cultural Studies”, p. 1-8, Crossref.

DAD = Charaudeau, P. \& Maingueneau, D. (eds), Dictionnaire d'analyse du discours, Editions du Seuil, Paris, 2002.

Dascălu-Jinga, L. (2009). Structuri clişeizate în romîna actualu, în Pană-Dindelegan, G. (coord.), Dinamica limbii române actuale - Aspecte gramaticale și discursive, Editura Academiei Romîne, București, p. 431-459.

Drăgan, I. (2007). Comunicarea: paradigme și teorii, Editura Rao International, București.

Duda, G. (2010). Semantica dezastrului, în „Analele Universității «Dunărea de Jos»”, anul III 1 (3), fascicula XXIV, Editura Europlus, Galați, p. 161-175.

Duda, G. (2016). Clişeul verbal și discursul public, Editura Academiei Române, București.

Dufays, J.L. (1994). Stéréotype et lecture, Mardaga, Liège.

Dumistrăcel, S. (2006). Discursul repetat în textul jurnalistic. Tentația instituirii comuniunii fatice prin mass-media, Editura Universității „Alexandru Ioan Cuza”, Iași.

Dumistrăcel, S. (2017). Cuvintele, încotro? Lingvistică pentru toate televiziunile, Editura Polirom, Iași.

Eco, U. (1979). Lector in Fabula: Pragmatic Strategy in a Metanarrative Text, în „The Role of the Reader: Explorations in the Semiotics of Texts", Indiana University Press, Bloomington, p. 200-266.

Felecan, D. (2009). Structuri clişeizate în horoscopul mediatic, în Rad, I. (ed.), Limba de lemn în presă, Editura Tritonic, București, p. 263-279.

Felecan, O. (2009). Limba de lemn în mesajele funerare de la mica publicitate, în Rad, I. (ed.), Limba de lemn în presă, Editura Tritonic, București, p. 280-293.

Gruiță, G. (2011). Moda lingvistică actuală: norma, uzul și abuzul, Editura Paralela 45, Pitești.

Guilbert, L. (1975). La créativité lexicale, Editura Larousse, Paris.

Guțu Romalo, V. (2008). Corectitudine și greșeală. Limba romînă de azi, ediția a III-a revăzută și adăugită, Humanitas, București. Hargraves, O. (2014). It's Been Said Before: A Guide to the Use and Abuse of Clichés, Oxford University Press, New York.

Kirkpatrick, B. (1996). Clichés: neither a Defence nor a Condemnation, în „English Today”, 12 (3), p. 16-25, Crossref.

Mackay, R.R. (2014). The Clichéd Juxtapositions and Pleasing Patterns of Political Advertising, în „Language \& Communication", 37, p. 100-119, Crossref.

Melinescu, N. (2013). Media îmbogățite: punct de întîlnire intre jurnalismul tradițional și noile platforme digitale, în Rad, I. (ed.), Jurnalismul tradițional și New Media, Editura Tritonic, București.

Nagy, R. (2015). Dicționar de analiză a discursului, Editura Institutul European, Iași. 
Nagy, R. (2016). Preliminarii teoretice la o analiză a clişeului/stereotipului din discursul artistic, în „Meridian critic”, 26, p. 7177.

Nina, A. (1998). La traduction du cliché dans les textes pragmatiques: définition, repérage, équivalences, [online].

Norberg, J. (2014). The Cliché as Complaint and Critique, în „FORUM: University of Edinburgh Postgraduate Journal of Culture \& the Arts", 18, [online].

Olimat, S.N. (2020). COVID-19 pandemic: Euphemism and dysphemism in Jordanian Arabic, în „GEMA Online Journal of Language Studies", 20 (3), p. 268-290, Crossref.

Olson, G. (1985). The Generational Cliché: Then You Saw It; Now They Don't, în "Journal of Advanced Composition”, 6, p. $105-115$.

Paraschivescu, R. (2009). Dintre sute de clişee: așchii dintr-o limbă tare, Editura Humanitas, București.

Perrin-Naffakh, A.M. (1985). Le cliché de style en français moderne: nature linguistique et rhétorique, fonction littéraire, Presses Universitaire de Bordeaux, Bordeaux.

Porter, R. (2010). From Clichés to Slogans: towards a Deleuze-Guattarian Critique of Ideology, în „Social Semiotics”, 20 (3), p. 233-245, Crossref.

Quéré, H. (1998). Le cliché: pour ou contre, în Gilles, M. (ed.), Le cliché, Presses Universitaires du Mirail, Toulouse, p. $101-112$.

Rad, I. (2013). Influența internetului asupra ştirilor din presa scrisă, în Rad, I. (coord.), Jurnalismul tradițional și New Media, Editura Tritonic, București.

Rafi, M.S. (2020). Language of COVID-19: Discourse of Fear and Sinophobia, Crossref.

Rajandran, K. (2020). 'A Long Battle Ahead': Malaysian and Singaporean Prime Ministers Employ War Metaphors for COVID19, în „GEMA Online Journal of Language Studies”, 20 (3), p. 261-267, Crossref.

Riffaterre, M. (1979). La Production du texte, Seuil, Paris.

Rovența-Frumuşani, D. (1999). Semiotică, societate, cultură, Institutul European, Iași.

Semino, E., Demjén, Z., Hardie, A., Payne, S., \& Rayson, P. (2017). Metaphor, cancer and the end of life: A corpus-based study, Routledge, New York, Crossref.

Shimko, K.L. (1995). Foreign Policy Metaphors: Falling "Dominos” and Drug “Wars”, în Neack, L., Hey, J. \& Haney, P. (eds), Foreign Policy Analysis. Continuity and Change in its Second Generation, Prentice Hall, Englewood Cliffs, p. 71-84.

Sontag, S. (1978). Illness as metaphor, Farrar, Straus and Giroux, New York.

Stark, R. (1999). Clichés and Composition Theory, în „Journal of Advanced Composition”, 19 (3), p. $453-464$.

Steuter, E. \& Wills, D. (2009). At War with Metaphor: Media, Propaganda, and Racism in the War on Terror, Lexington books. Stoichițoiu-Ichim, A. (2005). Vocabularul limbii române actuale. Dinamică, influențe, creativitate, Editura All, București. Stoichițoiu-Ichim, A. (2006). Creativitate lexicală în româna actuală, Editura Universității din București, București. Suhor, C. (1975). Clichés: A Re-assessment, în „College Composition and Communication”, p. 159-162, Crossref.

Tarde, G. (1979). Les lois de l’imitation: étude sociologique, prefață de Raymond Boudon, Slatkine, Paris (ed. I-a: 1890).

Thom, F. (1993). Limba de lemn, trad. Mona Antohi, Editura Humanitas, București.

Turner, B.S. (2003). Social Fluids: Metaphors and Meanings of Society, în „Body \& Society”, 9 (1), p. 1-010, Crossref. Vaisrub, S. (1977). Medicine’s Metaphors: Messages \& Menaces, Medical Economics Company, Oradell, NJ.

Yang, Z. (2020). Military metaphors in contemporary Chinese disease coverage: a case study of the People's Daily, 1946-2019, în „Chinese Journal of Communication”, p. 1-19, Crossref.

Zafiu, R. (2001). Diversitate stilistică în româna actuală, Editura Universității din București, București.

Zafiu, R. (2020). Covizi, în „Dilema veche”, nr. 853, 13-19 aug., [online].

Zijderveld, A.C. (1979). On Clichés: The Supersedure of Meaning by Function in Modernity, Routledge \& Kegan Paul, London, Boston and Henley. 